\title{
Between the flake and the blade: Associated systems of production at Riparo Tagliente (Veneto, northern Italy)
}

\author{
Leonardo Carmignani ${ }^{1,2,3,4}$
}

1. IPHES, Institut Català de Paleoecologia Humana i Evolució Social, Campus Sescelades (Edifici W3), 43007, Tarragona, Spain.

2. Universitat Rovira i Virgili, Department of History and Art History, Campus Catalunya,

Av. Catalunya, 35, 43002, Tarragona, Spain.

3. Università degli Studi di Ferrara, Dipartimento di Studi Umanistici,

C.so Ercole I d'Este 32, 44100, Ferrara, Italy.

4. UMR 7041 ArScAn, Anthropologie des Techniques, des Espaces et des Territoires au Pliocène et Pléistocène (AnTET), Maison de l'Archéologie et de l'Ethnologie 21 allée de l'Université 92023 Nanterre Cedex, France.

Email: leonardo.carmignani76@gmail.com

\begin{abstract}
:
The Riparo Tagliente site (Verona, Italy) shows three macro phases in which high technological variability can be observed. The aim of this study is to evaluate the specific role of the Middle Paleolithic blade production within this variability. Preliminary results show a complex scenario in which the role of the blade is strictly linked with flake production through mixed reduction systems.

Two different approaches were used for analysing the lithic assemblages from the site. The first analysis focused on the identification of the reduction systems by determining the techniques, methods and concepts underlying the entire chaîne opératoire. The second approach concentrated on analysing blade production in order to identify its variability.

Evidence of blade technology from the Middle Pleistocene (MIS 8-6) has been found in northern Europe (France, Belgium). Later, during MIS 5 blades can be found over a larger area, this time also including north-western Germany and the central-southern part of France. A third period (MIS 4-3) marks the appearance of laminar production in southern Europe, including in the Italian peninsula. Based on the present state of research these three phases appear to be on-and-off events without clear evolutionary continuity.

By repositioning the sequence of Riparo Tagliente within the Italian context we can observe that at the end of the Mousterian period the technological patterns differ greatly, with laminar production being one of its most evident expressions. The origin of this fragmentation is questionable.
\end{abstract}

Keywords: blades; Riparo Tagliente; Middle Paleolithic; Levallois; reduction systems

Published by the School of History, Classics and Archaeology, University of Edinburgh ISSN: 2055-0472. URL: http://journals.ed.ac.uk/lithicstudies/

This work is licensed under a Creative Commons Attribution 2.5 UK: Scotland License. 


\section{Introduction}

By simplifying what is produced through lithic production, we can identify three possible categories of products: flakes and blades, both produced by knapping operations (débitage), and shaped tools (hand axes, choppers), the result of shaping operations (façonnage). If shaping operations involve a conceptual modelling structure of a block of raw material, the dichotomy flake-blade is, at the macroscopic scale, a double variant of the same theme, which entails the separation of a piece from its original volume. The Middle Paleolithic marks the emergence and development of a variety of knapping methods aimed at producing predetermined blanks within which the blade occupies a not-yet defined role.

This paper addresses the issue of the technological complexity that characterizes Middle Paleolithic reduction systems and investigates the role of elongated products within the Neanderthal techno-cultural baggage. In addition to Levallois production, the sequence of Riparo Tagliente shows the use of various reduction systems aimed at obtaining a mixture of flake and blade blanks. Because of this a comparison of the morpho-technical characteristics of Levallois and non-Levallois elongated products was carried out.

\subsection{The blade phenomenon in the Middle Paleolithic}

From a global point of view, blade production dates back to the Middle Pleistocene. The first evidence of blade production was found in Africa at two sites, Kathu Pan (Wilkins \& Chazan 2012) and Kapturin (Johnson \& McBrearty 2010), both approximately 500,000 years old (Figure 1).

The Amudian complex in the Middle East is the second oldest evidence of blade production and dates back to MIS 9 and MIS 8 (Mercier \& Valladas 2003; Barkai et al. 2005).

Subsequently, in a second phase (MIS 7-6), the expansion and differentiation of blade production over a larger area took place, which included the internal part of Syria and the southern area of the Caucasus. This second phase gave rise to several other lithic industries known by various names: the Hummalian (Le Tensorer 2005; Richter et al. 2011), PreAurignacian (Bordes 1977), Hayonim (Meignen 2011), and Djruchula-Koudaro industries (Meignen \& Tushabramishvili 2006; 2010).

The third and final phase is that of the well-known case of the northern European blade production observed at several sites dating back to MIS 8 and MIS 7 (Révillion 1995).

By contrast, there is no evidence of blade tool production in Asia, at least during the Middle Pleistocene (Boëda et al. 2013; Li \& Bodin 2013; Peng et al. 2014). The easternmost assemblages containing volumetric blade technology have been documented at Khonako in Tadjikistan and date back to around 170 ka (Schäfer \& Ranov 1998; Schäfer et al. 1998; 2003).

All of these industries have in common the presence of blades, but differ strongly in the rest of their productions (Meignen 1994; 2007).

In short, during the Middle Pleistocene at least three blade production epicentres differentiated in space and time can be observed. As far as we know these spatial, chronological and technological differences suggest a convergence phenomenon (Figure 1). 


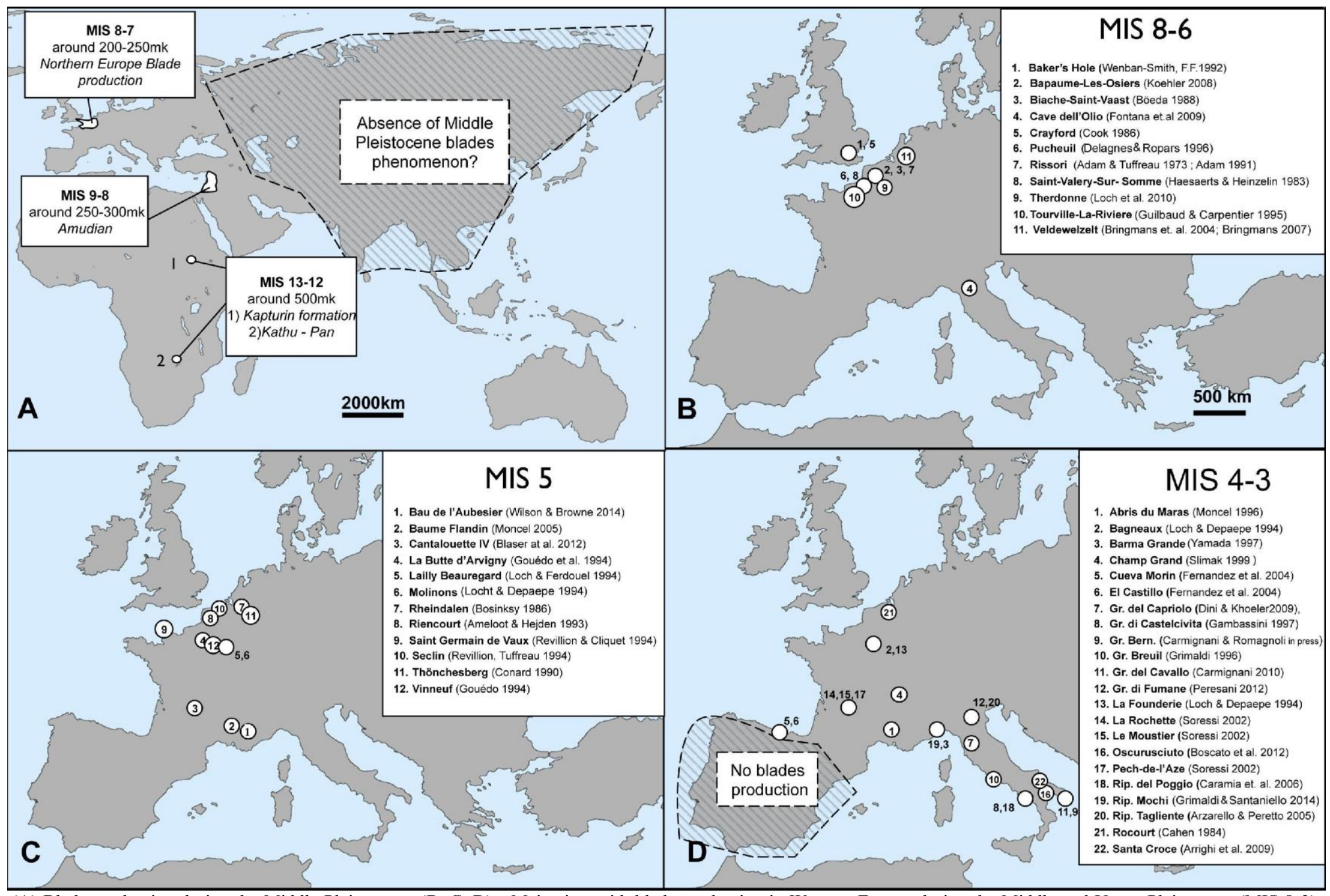

Figure 1. (A) Blade production during the Middle Pleistocene. (B, C, D) - Main sites with blade production in Western Europe during the Middle and Upper Pleistocene (MIS 8-3). (Adapted blank maps from Free Software Foundation (FSF), GNU General Public License). 
We will now focus our attention on the European continent, where, as was already noted, the earliest evidence of laminar production dates back to MIS 8 and MIS 7 and is found in northern Europe. The reduction systems used were either volumetric, such as those of SaintValéry-sur-Somme (Heinzelin \& Haesaerts 1983), Bapaume-les Osiers (Koehler 2008) and Therdonne (Locht et al. 2010) in France, Rissori (Adam 1991; Adam \& Tuffreau 1973) in Belgium, or followed a Levallois concept, as noted at the site of Biache-Saint-Vaast in northern France (Böeda 1988) (Figure 1). We know these productions continued throughout MIS 7, but there is a lack of archaeological evidence for the glacial peak that was MIS 6 . Further east, the sites of Kabazi, Molodova, and Kolorevo show blade production starting in MIS 7 (Chabai \& Sitlivyj 1994; Chabai et al. 2004).

During MIS 5 blade production becomes, once again, abundant in northern Europe as exemplified by the French and Belgian sites of Riencourt lès-Bapaume (Ameloot-Van der Hejden 1993; Goval \& Hérisson 2006), Saint-Germain-des-Vaux (Cliquet 1992; Révillion \& Cliquet 1994), Seclin (Révillion \& Tuffreau 1994), Bettencourt-Saint-Ouen (Loch 2002), Blangy-Tronville (Depaepe et al. 1999), and Rocourt (Otte 1994a).

At the same time, blade production also spread over a wider area including northeast Germany (Tönchesberg (Conard 1990) and Wallertheim sites (Conard \& Adler 1997)) and central and southern France (Angé (Locht et al. 2008), Vinneuf (Gouédo 1994), Baume Flandin (Moncel 2005; Moncel et al. 2008) and Cantalouette 4 sites (Blaser et al. 2012)) (Figure 1).

In all of the above sites blades were rarely the predominant tool types, but instead coexisted with various other reduction systems (Levallois, Discoid, etc.) as well as with a number of shaping systems such as those noted at the sites of Bapaume-les Osiers (Koehler 2008) and Vinneuf (Gouédo 1994) in France. In the MTA B industries, the association of blade reduction systems with hand axe is also well documented (Soressi 2002; 2005).

The variability of the blade reduction systems used does not allow for these to be grouped based on a common denominator. Knapping can begin with the preparation of a crested blade or by exploiting the natural convexity of the raw material. Both unidirectional or bidirectional methods are applied for directing the removals. Exploitation can be applied to the narrow surface by means of a rotating or semi-rotating rhythm ('volumetric latu sensu') or to a configured large surface ('Levallois concept').

There is still ongoing debate concerning the origin of these production systems. Some authors have suggested that blade production could be an opportunist method leading to the optimisation of the use of the raw materials, which may have motivated the production of elongated removals (Conard 1990). However, this may not necessarily be the case in areas rich in raw materials, where these productions are equally present. Furthermore, the use of different raw material geometric structures such as pebbles, nodules, core-flakes or slabs does not appear to have been hindered or limited the production of blades. Other authors have suggested a relationship between blade production and environmental crises (Otte 1994b). However, the duration of the blade phenomenon and the diffusion in areas that differ greatly from one another suggest that it is impossible to provide a single explanation for it.

This phenomenon only appeared in southern Europe at a later stage. Blades first appear in the south of France in MIS 5, as in the site of Cantaluette 4 (Blaser et al. 2012), but become more widespread during MIS 4 and MIS 3 such as in the site of Abris du Maras (Moncel 1996) and Champ Grand (Slimak 1999) (Fig 1).

This final phase of Middle Paleolithic blade production is also comparable to the lithic industries observed in central Europe such as the Bohunician (Svoboda \& Skrdla 1995; Skrdla 2003). 
In short, we can observe how the oldest expressions of the laminar phenomenon occurred within the northern borders for a long time (MIS 8-6) while the southern regions were still dominated by the production of flakes (Figure 1).

As far as the Italian peninsula is concerned, current studies report the first evidence of blade production in the final phases of the Middle Paleolithic, more specifically in MIS 4 and in the first part of MIS 3 (Figure 1). The geographic distribution of both non-Levallois and Levallois blade production does not appear to be linked to a specific area or environment. In fact these productions can be found all throughout the Italian peninsula.

Non-Levallois productions were found in the Apulia region at the sites of Santa Croce (Arrighi et al. 2009) and Grotta del Cavallo (Carmignani 2010); in Lazio at Grotta Breuil (Grimaldi 1996); in Molise at Grotta Reali (Arzarello et al. 2004; Peretto 2012); in Veneto at Fumane (Peresani 2012); and in Liguria at Grotta di San Francesco (Tavoso 1988) and Madonna dell'Arma (Cauche 2007; Cauche \& Lebègue 2008).

At the same time Levallois blade production is well represented both in northern Italy at Riparo Mochi (Grimaldi \& Santaniello 2014; Yamada 2004) and Barma Grande (Yamada 1997) and in the south at Riparo del Poggio (Caramia \& Gambassini 2006), Grotta di Castelcivita (Gambassini 1997) and Oscurusciuto (Boscato et al. 2011; De Stefani et al. 2012).

The only exception to this late appearance in the Italian peninsula is the site of Cave dell'Olio (Fontana et al. 2009; Fontana et al. 2013). This site is, at the present, the only one dating back to MIS 9, representing the only proof of blade production in the Italian Peninsula during the Middle Pleistocene.

While it is now certain that blades were produced during the Middle Paleolithic, the production of bladelets, obtained by means of an independent reduction system, is less evident and occurred just in the final phases of the Mousterian period. Some bladelets production has been noted at the sites of El Castillo and Cueva Morin in northern Spain (Maíllo Fernández 2001; Maíllo-Fernández et al. 2004), at Champ Grand (Slimak \& Lucas 2005) and Combe Grenal in France (Faivre 2012), Fumane (Peresani et al. 2013) and Grotta del Cavallo in Italy (Carmignani 2010) and Balver Höhle in Germany (Pastoors \& Tafelmaier 2010).

Some geographic areas, such as the Balkans and Greece, and the Iberian Peninsula, do not seem to be influenced by this phenomenon, both during its earliest and more recent phases, completing the fragmentary and irregular overview that emerges from the data in our possession.

Although this absence can be attributed to a lack of research, especially for the Balkan region and Greece, this is certainly not the case for the Iberian Peninsula for which there is a much larger amount of available data.

The Riparo Tagliente site, which is presented in this paper, is part of the last phase of the Middle Paleolithic blade phenomenon and shows an articulated techno-cultural repertoire consisting of mixed flake and blade reduction systems.

\section{Materials and methods}

\subsection{The site of Riparo Tagliente}

Riparo Tagliente is a rock shelter located in the Veneto region in northern Italy (Figure 2). It was first excavated in the 1960s by the Museo Civico di Storia Naturale di Verona (Pasa \& Mezzena 1964; Zorzi 1962; Zorzi \& Mezzena 1963) and subsequently in collaboration with the University of Ferrara (Bartolomei et al. 1982; 1984). The Mousterian collection under examination here comes from these excavations. Research at the site is still ongoing currently under the direction of Federica Fontana from the University of Ferrara. Sediment, 
macrofaunal, microfaunal and pollen analyses date the Mousterian sequence between MIS 4 and the beginning of MIS 3 (Arzarello et al. 2007; Cattani \& Renault-Miskovsky 1989; ThunHohenstein \& Peretto 2005). The stratigraphy, excavated by artificial layer, is composed of a Mousterian sequence and an Epigravettian sequence separated by erosion. The 1960s excavation procedures, which paid much attention to sedimentary details, have enabled us to determine light patterns of internal evolution of the lithic industry.
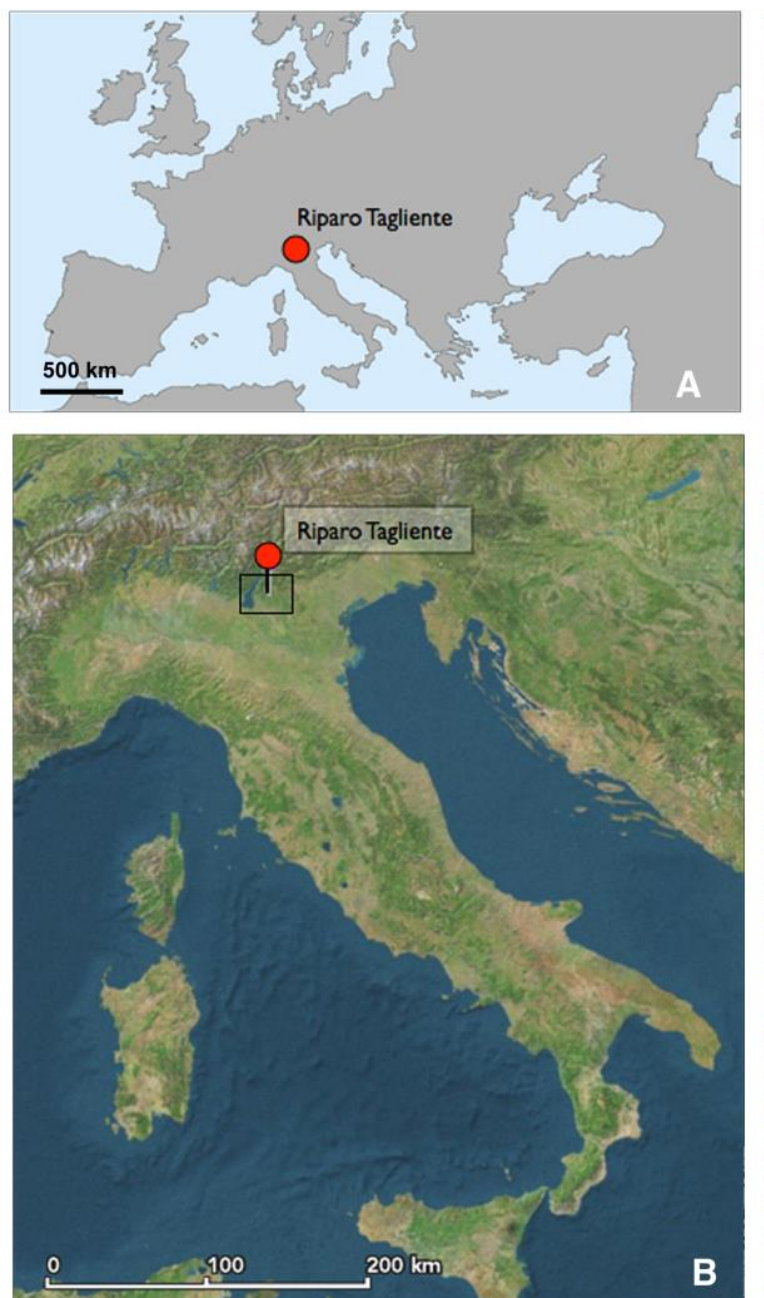
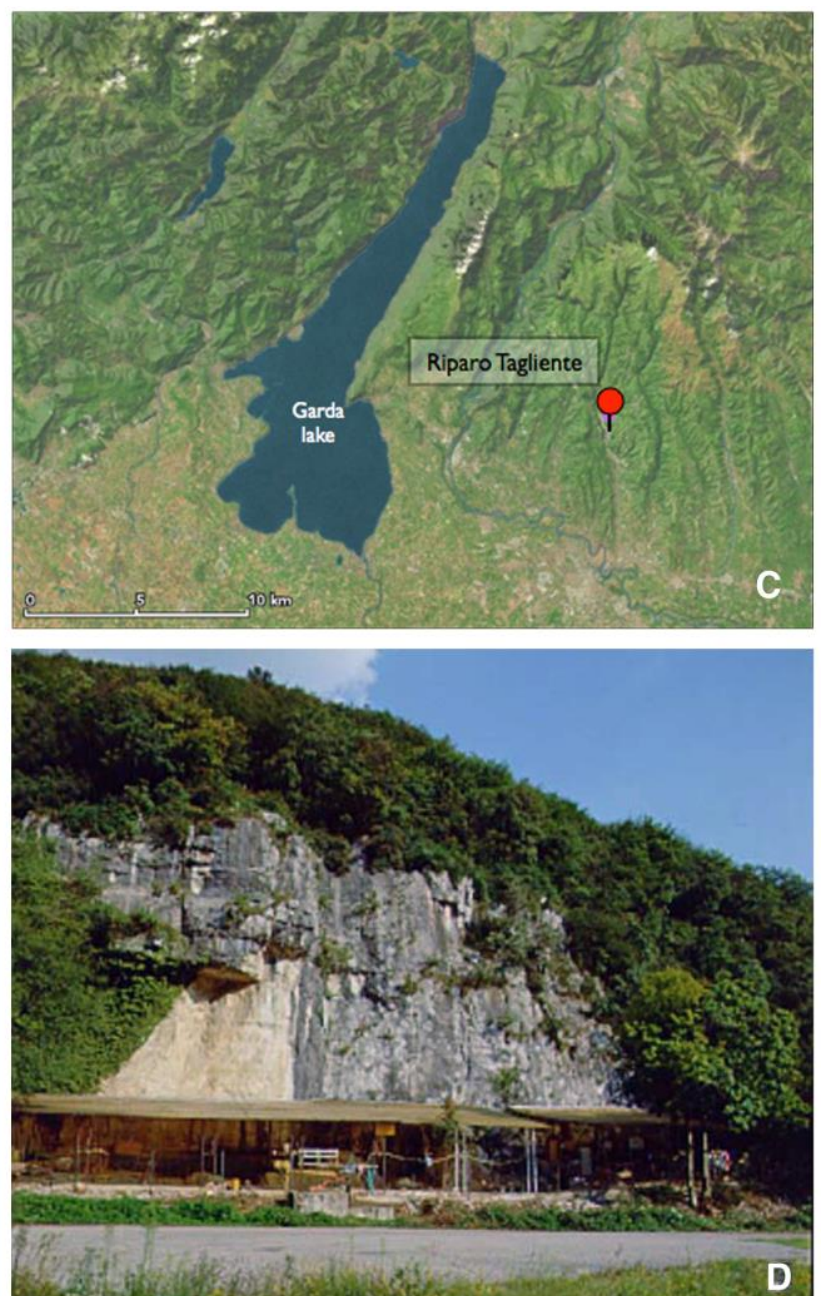

Figure 2. (A, B, C) Maps showing the position of Riparo Tagliente; (D) view of Riparo Tagliente (from Arzarello 2003).

The Mousterian sequences have been found in two different locations known as 'Internal shelter' and 'External shelter' (Figure 3). The Internal shelter comprises 18 layers (52 to 34) and extends over $8 \mathrm{~m}^{2}$ while the External shelter comprises 13 layers (46 to 34) and a larger surface area $\left(16 \mathrm{~m}^{2}\right)$.

\subsection{Sorting procedure and methodology}

In Medieval times the shelter has been used as a refuge. These occupations caused a partial destruction and reshuffle of the deposits on a quite large area both for the Epigravettian layers as well as for the Mousterian's ones.

For these reasons a preliminary check of the material and stratigraphy has been focused on eliminating the squares and the layers considered not reliable. After the check we have considered as being reliable just four squares coming from the Internal shelter (Q 614, 615, 634, 635) and four squares coming from the External shelter (Q 5, 6, 8, 9) (Figure 3). In the same way the layers 34 and 35, have been as well excluded from our analysis because of the 
presence of contamination coming from the Epigravettian layers. After the sampling, our analysis has been concentrated on the layers going from 52 to 36 on an area of $9 \mathrm{~m}^{2}$. We have selected all flakes (complete or broken) bigger than $15 \mathrm{~mm}$. All cores, core fragments, tools, tool fragments and all blades and blade fragments are selected regardless of their size. The distribution of the material across the sequence show different concentration of the material that has been possible to group in three macro phases called Lower layers, Intermediate layers and Upper layers (Figure 3). Five layers show a high density of stone artefacts (more than 200 pieces). Three layers contain less than 5 pieces and can therefore be considered as sterile (Figure 3).

A

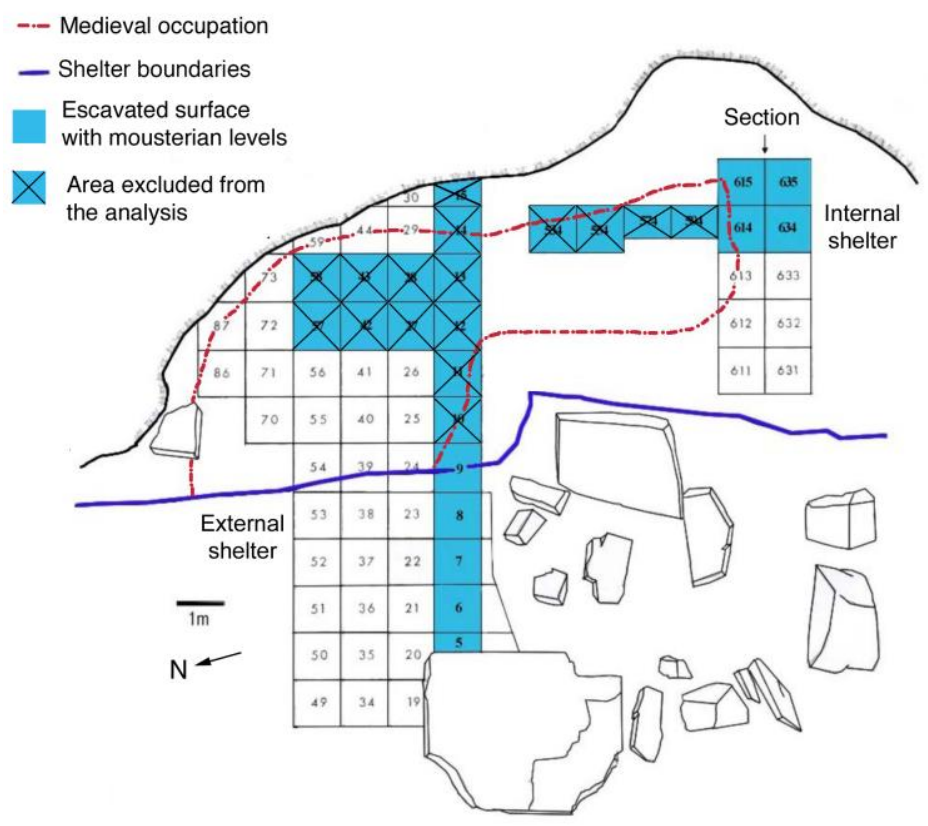

$\mathrm{B}$

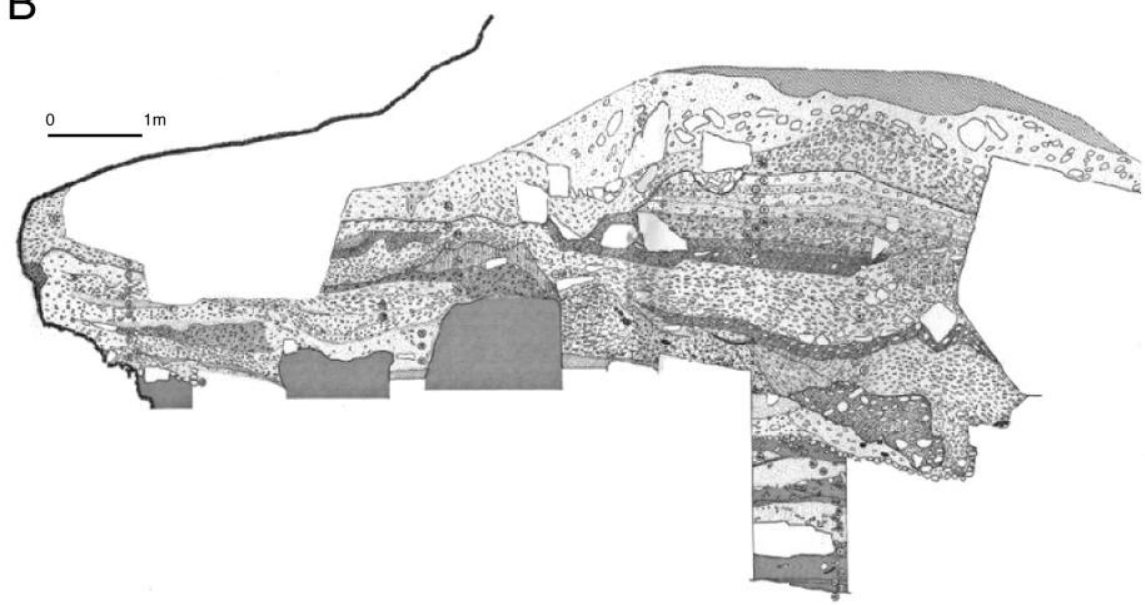

C

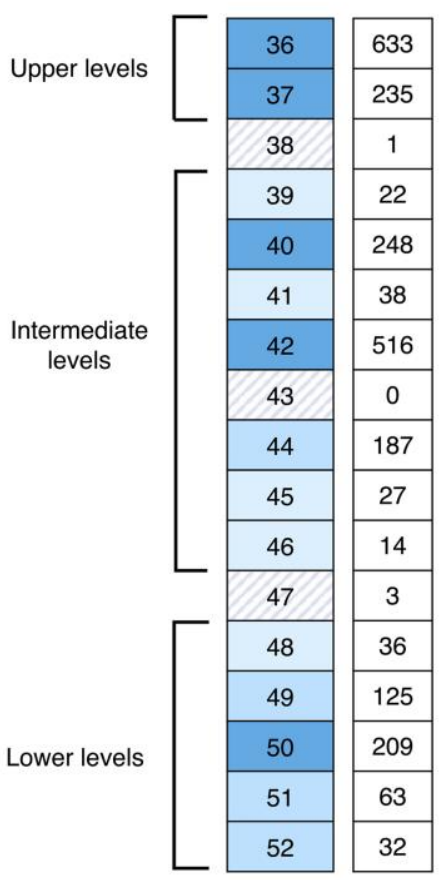

Number of pieces in each level

\begin{tabular}{|c|}
\hline High density $>200$ pieces \\
\hline Medium density $>100$ pieces \\
\hline Low density $<100$ pieces \\
\hline Sterile layer $<5$ pieces \\
\hline
\end{tabular}

Figure 3. (A) Plan showing the excavation areas (Modified after Bartolomei et al. 1982). (B) Stratigraphic section between squares 5/15 and 505/515, and layers 43 to 31 (Modified after Arzarello 2003). (C) Lithic industry distributions across the sequence.

The lithic products of Riparo Tagliente were analysed using a technological approach. The knapping system analysis follows the same principles as those of the chaîne operatoire analysis, which is supported by the quantitative presentation of technological categories (Inizan et al. 1995). The definition suggested by Boëda (1994) was adopted for the Levallois 
concept. Given the absence of the refitting reconstruction of the reduction sequences we used the mental refitting method (Pelegrin 1995). The techniques were identified according to experimental studies carried out by Pelegrin (1991; 2000). Volumetric and Levallois blade productions were distinguished by means of volumetric structure analyses (Boëda 1990). In terms of the Discoid production, we used the definition put forward by Boëda $(1993 ; 1991)$ as well as also taking in consideration broader criteria (Peresani 1998; Slimak 2003). Diacritical analyses were applied to cores and blanks as a means to reconstruct the chronological order of the scars (Dauvois 1976).

\section{Results}

\subsection{Lithic technology}

Our database contains a total of 2315 débitage removals and 75 cores. The raw material used is good quality flint from local sources $(<5 \mathrm{~km})$. The flint was collected mainly in secondary position in the form of pebbles and to a smaller extent in primary position as roundish nodules (Arzarello et al. 2007). Production mainly comprised flakes and to a lesser extent blades (Table 1).

Table 1. Riparo Tagliente. Frequencies of débitage classes and cores

\begin{tabular}{|c|c|c|c|c|c|c|}
\hline & \multicolumn{2}{|c|}{$\begin{array}{l}\text { Lower layers } \\
\text { from } 52 \text { to } 47\end{array}$} & \multicolumn{2}{|c|}{$\begin{array}{l}\text { Intermediate layers } \\
\text { from } 46 \text { to } 39\end{array}$} & \multicolumn{2}{|c|}{$\begin{array}{l}\text { Upper layers } \\
\text { from } 38 \text { to } 36\end{array}$} \\
\hline & no. & $\%$ & no. & $\%$ & no. & $\%$ \\
\hline Levallois centripetal flakes & 20 & 4.3 & 90 & 8.6 & 36 & 4.1 \\
\hline Levallois unidirectional flakes & 22 & 4.7 & 36 & 3.4 & 16 & 1.8 \\
\hline Levallois orthogonal flakes & 0 & - & 1 & 0.1 & 1 & 0.1 \\
\hline Levallois convergent flakes & 1 & 0.2 & 7 & 0.7 & 4 & 0.5 \\
\hline Levallois flakes with a back & 4 & 0.9 & 15 & 1.4 & 2 & 0.2 \\
\hline Centripetal flakes & 51 & 10.9 & 96 & 9.1 & 74 & 8.5 \\
\hline Unidirectional flakes & 48 & 10.3 & 83 & 7.9 & 26 & 3.0 \\
\hline Bidirectional flakes & 4 & 0.9 & 10 & 1.0 & 2 & 0.2 \\
\hline Orthogonal flakes & 0 & - & 11 & 1.0 & 3 & 0.3 \\
\hline Sub-convergent flakes & 5 & 1.1 & 14 & 1.3 & 5 & 0.6 \\
\hline Convergent flakes & 3 & 0.6 & 7 & 0.7 & 1 & 0.1 \\
\hline Debordant flakes (unspecified) & 11 & 2.4 & 21 & 2.0 & 7 & 0.8 \\
\hline Debordant flakes (centripetal) & 4 & 0.9 & 16 & 1.5 & 7 & 0.8 \\
\hline Debordant flakes (unidirectional) & 4 & 0.9 & 7 & 0.7 & 0 & - \\
\hline Debordant flakes (bidirectional) & 0 & - & 7 & 0.7 & 0 & - \\
\hline Pseudolevallois points & 0 & - & 2 & 0.2 & 4 & 0.5 \\
\hline Kombewa 1st generation & 9 & 1.9 & 17 & 1.6 & 5 & 0.6 \\
\hline Kombewa 2nd generation & 5 & 1.1 & 14 & 1.3 & 5 & 0.6 \\
\hline Levallois blades & 3 & 0.6 & 18 & 1.7 & 7 & 0.8 \\
\hline Non Levallois blades & 28 & 6.0 & 56 & 5.3 & 48 & 5.5 \\
\hline Crested blade & 1 & 0.2 & 0 & - & 0 & - \\
\hline Cortical flakes & 79 & 16.9 & 186 & 17.7 & 180 & 20.7 \\
\hline Striking platform flakes & 11 & 2.4 & 5 & 0.5 & 6 & 0.7 \\
\hline Unspecified flakes & 57 & 12.2 & 123 & 11.7 & 170 & 19.5 \\
\hline Undetermined fragments $>15 \mathrm{~mm}$ & 73 & 15.6 & 165 & 15.7 & 256 & 29.4 \\
\hline Cores & 25 & 5.3 & 45 & 4.3 & 5 & 0.6 \\
\hline Total & 468 & 100.0 & 1052 & 100.0 & 870 & 100.0 \\
\hline
\end{tabular}


Hard hammer direct percussion was the only technique used in all the reduction systems. The abundance of cortical flakes proves that the initial stage of knapping activities was carried out at the site (Table 1).

In terms of the knapping products, all the layers show a high degree of homogeneity as shown by the large number of Levallois flakes derived from centripetal and unidirectional methods (Table 1). Generic unidirectional and centripetal flakes are numerous. Unidirectional flakes, the number of which falls in the upper layers, represent the only element of discontinuity across the sequence. Blade production is distributed in similar percentages throughout the sequence and is composed of both Levallois and non-Levallois blades (Table 1). Production also includes convergent, orthogonal, bidirectional and Kombewa flakes that are present in small numbers throughout the sequence. The apparent homogeneity observed when analysing the knapping products will be partially invalidated when we turn our attention to the analysis of the cores.

\subsubsection{Lower layer reduction systems}

The Lower layers contain 468 lithic pieces of which 25 are cores. As is the case with the end product, the cores indicate that the Levallois is the main reduction system, which is predominantly expressed in the centripetal method and secondarily in the unidirectional method (Figure 4). The purpose of using the Levallois unidirectional system was to produce mostly flakes. Few blades are associated with this system.

The second most adopted system is based on the exploitation of cortical thick flakes by means of the Kombewa system (Table 2). The exploitation can be limited to a singular detachment or to a short sequence of detachments (Figure 5). The preparation of the cores is limited to a partial correction of the lateral convexities of the flaking surface.

Table 2. Riparo Tagliente. Core types.

\begin{tabular}{|c|c|c|c|c|c|c|c|c|c|c|c|}
\hline & \multicolumn{5}{|c|}{ Lower layers } & \multicolumn{5}{|c|}{ Intermediate layers } & \multirow{2}{*}{$\begin{array}{l}\text { Upper layers } \\
\text { t36 (total) }\end{array}$} \\
\hline & $\mathrm{t} 52$ & t50 & t49 & $\mathrm{t} 48$ & total & t46 & t44 & $\mathrm{t} 42$ & $\mathrm{t} 40$ & total & \\
\hline Levallois centripetal & - & 3 & 3 & - & 6 & - & - & 16 & - & 16 & 3 \\
\hline Levallois unidirectional & - & 1 & - & 1 & 2 & - & - & 3 & - & 3 & - \\
\hline Levallois bidirectional & - & - & - & - & - & - & - & 1 & 1 & 2 & - \\
\hline Levallois preferential & - & - & - & - & - & - & 1 & 5 & - & 6 & 1 \\
\hline Levallois initialized & - & - & - & - & - & - & - & 3 & - & 3 & - \\
\hline Discoid & 1 & 1 & - & - & 2 & 1 & - & 1 & - & 2 & - \\
\hline SSDA & - & 1 & 2 & - & 3 & 1 & - & 2 & - & 3 & - \\
\hline Kombewa (single removal) & - & 1 & 3 & - & 4 & - & - & - & - & - & - \\
\hline Kombewa (multiple removal) & - & 2 & 1 & - & 3 & - & - & - & - & - & - \\
\hline Semi pyramidal & - & - & 2 & - & 2 & - & - & - & - & - & - \\
\hline Unidirectional Type 1 & - & 1 & 1 & - & 2 & - & - & - & - & - & - \\
\hline Unidirectional Type 2 & - & - & - & - & - & 1 & - & 6 & 1 & 8 & 1 \\
\hline Bidirectional & 1 & - & - & - & 1 & - & - & 2 & - & 2 & - \\
\hline Total & 2 & 10 & 12 & 1 & 25 & 3 & 1 & 39 & 2 & 45 & 5 \\
\hline
\end{tabular}

Two cores show a unidirectional reduction system composed of two different exploitation yet interconnected phases, which we termed Unidirectional Type 1 (Figure 6). The first phase exploits the larger surface of the volume through a short unidirectional sequence and has two complementary functions: to produce quadrangular, slightly elongated flakes and to reduce the thickness of the adjacent surface, which will be exploited by a second unidirectional sequence (second phase). The exploitation of the thinner side of the volume, already reduced in thickness during the first sequence, allows for the production of small 
blades (Figure 6). The configuration of cores is limited to a partial preparation of the lateral convexities carried out by means of a series of orthogonally-oriented detachments with regard to the main flaking direction. An isolated core shows a bidirectional exploitation starting from two opposite striking platforms. The variability of the production systems in this unit is also composed of two Discoid cores and two sub-pyramidal cores. The sub-pyramidal cores are aimed at producing thick convergent flakes (Figure 5). Four cores follow a reduction system based on the exploitation of orthogonal alternated surfaces that can be associated with a SSDA system (Forestier 1993) or with an opportunistic method, sensu Arzarello (2003).
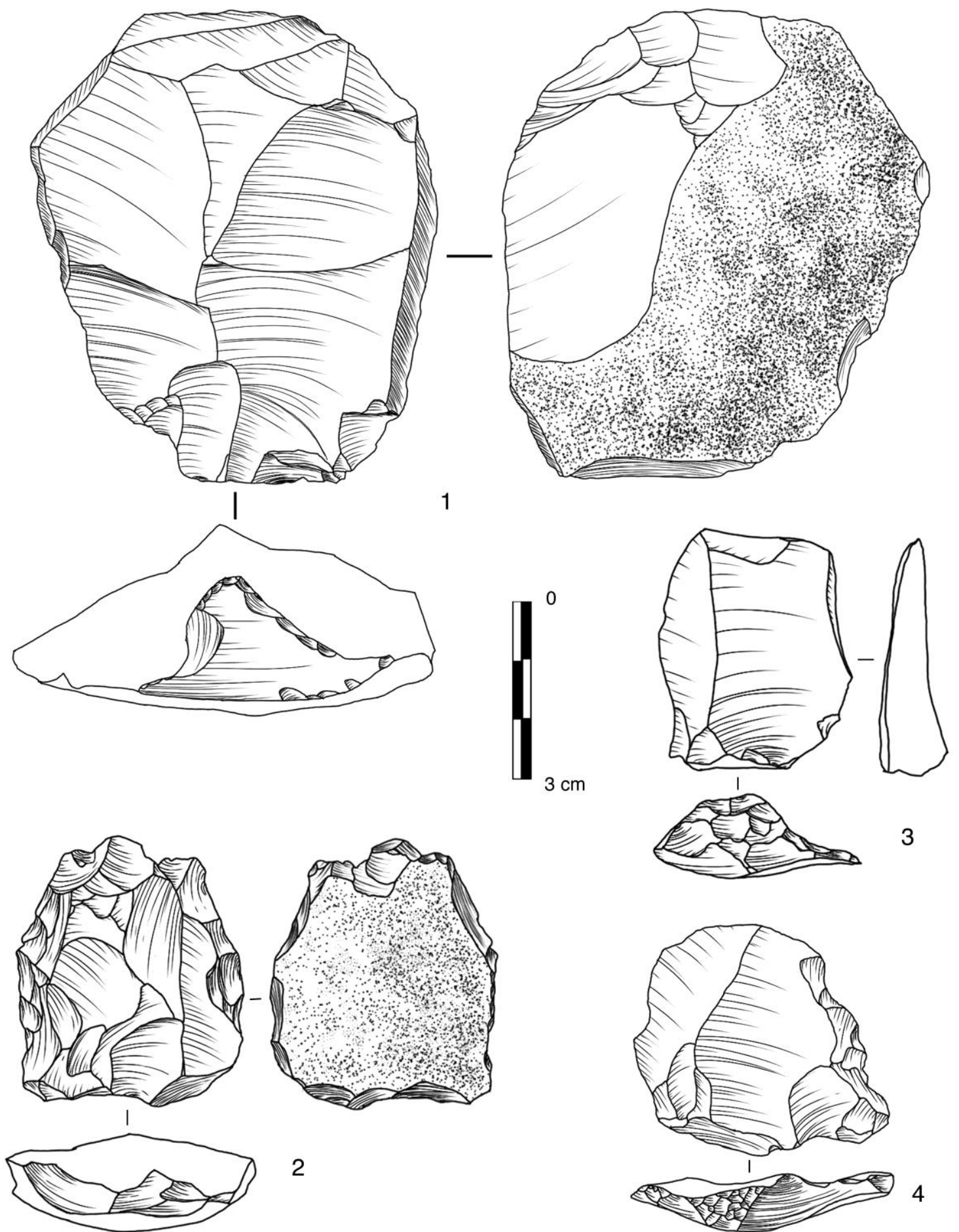

Figure 4. Riparo Tagliente. Lithic industries from the Lower Layers. (1) Levallois unidirectional core; (2) Levallois centripetal core; (3) Levallois unidirectional flake; (4) Levallois centripetal flake. 

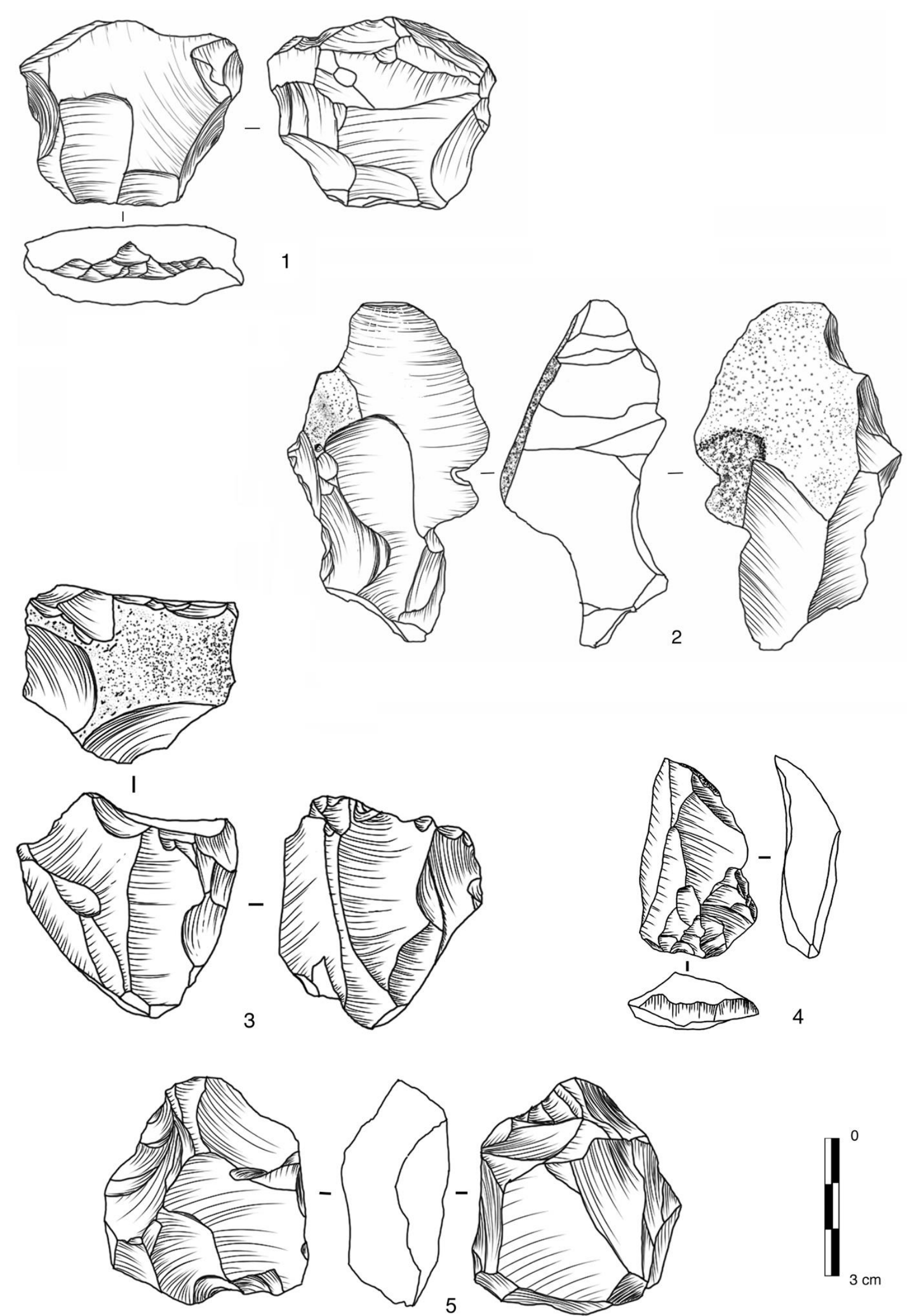

Figure 5. Riparo Tagliente. Lithic industries from the Lower Layers. $(1,2)$ Kombewa cores; (3) Half-pyramidal core; (4) Convergent flake; (5) Discoid core. 

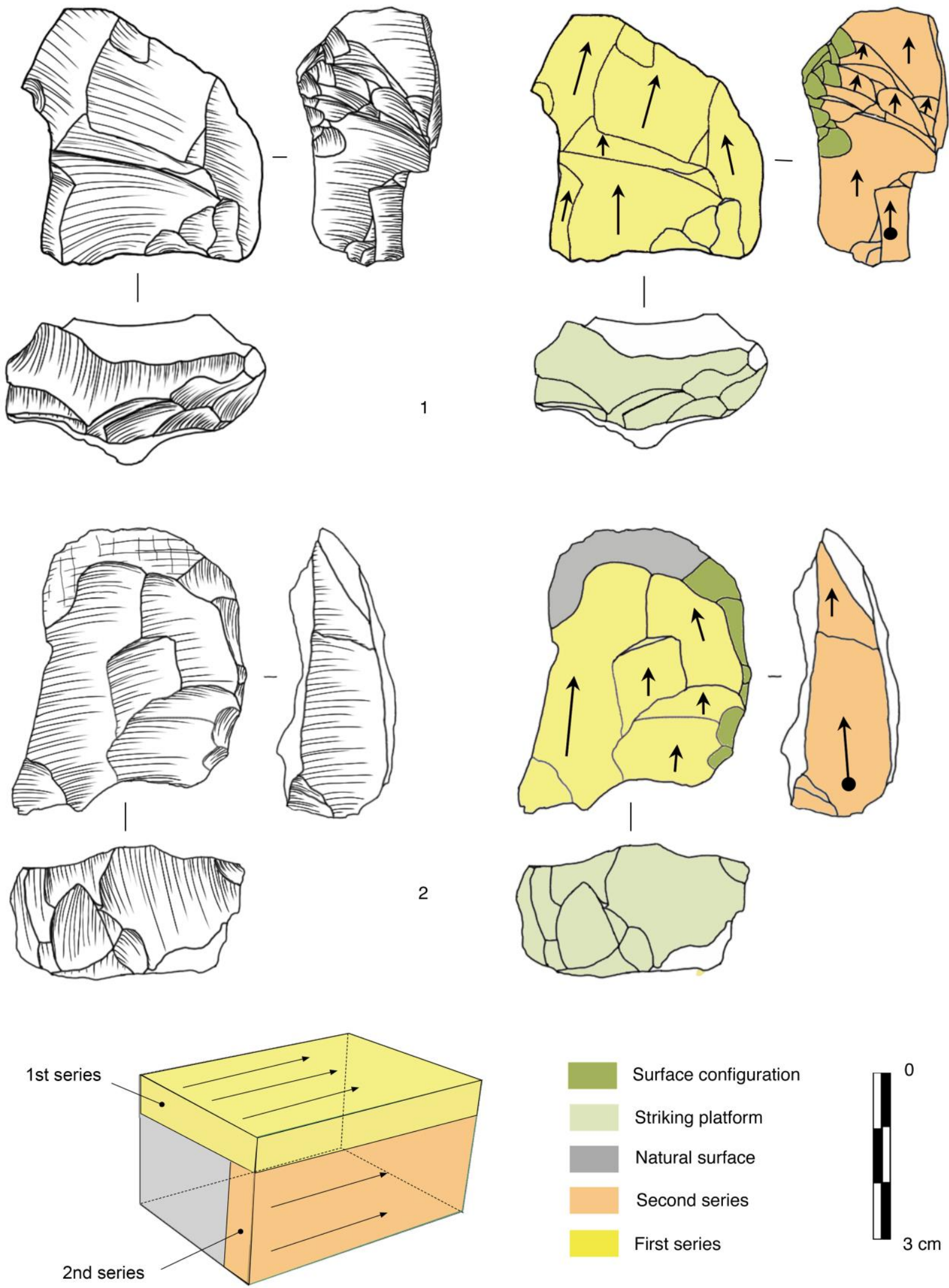

Figure 6. Riparo Tagliente. Lithic industries from the Lower Layers. Unidirectional system Type 1 cores.

\subsubsection{Intermediate layers reduction systems}

The Intermediate layers of Riparo Tagliente show some elements of continuity with the Lower layers such as the persistence of the Discoid and SSDA systems. The centripetal 
Levallois continues to be the predominant reduction system, however, the plasticity of the Levallois concept finds greater variability here than it does in the Lower layers. The centripetal and unidirectional methods are supported by a bidirectional exploitation while the use of the preferential method, totally absent in the Lower layers, is well represented here (Figure 7).

No Kombewa cores were noted in the Intermediate layers. The presence of Kombewa flakes in these layers could indicate the export of the cores outside the site or they could derive from other flaking operations such as the configuration of a Levallois surface based on the exploitation of the ventral face of a flake. The absence of pyramidal and unidirectional system type 1 methods is a further element of divergence compared to the Lower layers.

In the Intermediate layers the most common production system consists of a unidirectional system which tends to develop around the edge of the core following a semirotating rhythm (Unidirectional core type 2) (Figure 7). There is no or minimal flaking surface preparation. The maintenance of the core convexities is evident in some debordant blades and plunging laminar blanks. The end products consist of elongated thick blanks.

\subsubsection{Upper layer reduction systems}

The lack of cores roughly sums up the reduction systems in the Upper layers. However, based on the end products, we can see a certain continuity with the Intermediate and Lower layers represented by a large number of Levallois flakes. As for the Intermediate layers, the Levallois concept shows great variability expressed in the convergent, unidirectional and bidirectional methods (Figure 8). The unidirectional semi-rotating system (Unidirectional Type 2) is only observed in one core.

\subsection{Retouched pieces}

Three different categories were established in order to study the retouched pieces. Each of these categories corresponds to the number of transformation degrees undergone by the blanks: low, medium and high degrees (Figure 9).

The low degree describes a marginal retouch of the perimeter of the piece, which does not modify the cutting edge nor the morphology of the pieces in any way. The medium degree consists of a retouch that modifies the morphology of the cutting edges, but not the structure of the piece.

The high degree refers to the structural modification of the blanks, which completely or partially transforms their original morphology.

Transformation through retouching can be noted in all layers. The Lower layers show the highest percentage of transformation while the lowest percentages are observed in the Intermediate and Upper layers (Table 3).

The retouching phase shows different degrees of transformation in terms of the débitage classes. Besides a few rare exceptions, high levels of transformation are mainly observed in the cortical and generic flakes found in all three layer groups (Table 4). On the other hand, Levallois flakes only show slight modifications just like in the blade production (Figure 9). 

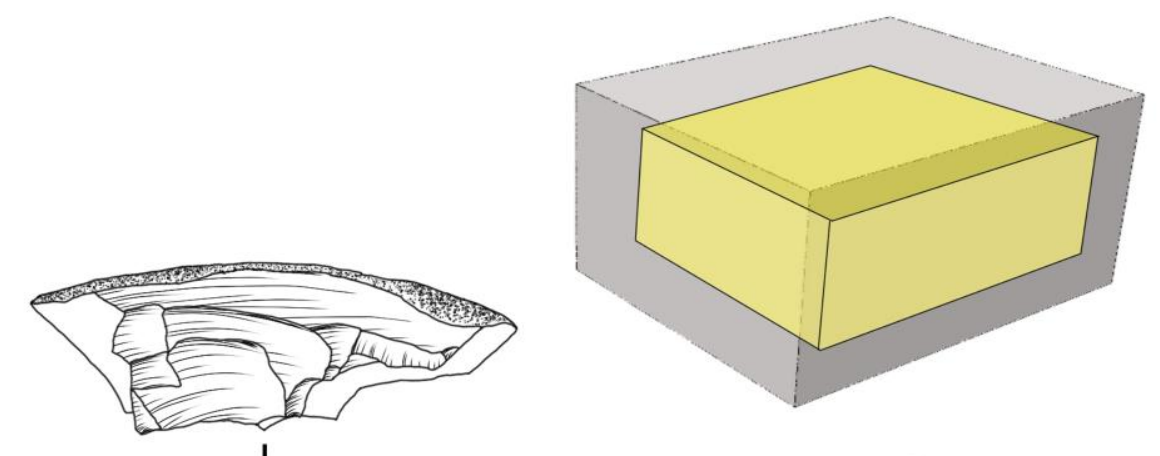

Total configuration

"Levallois concept"
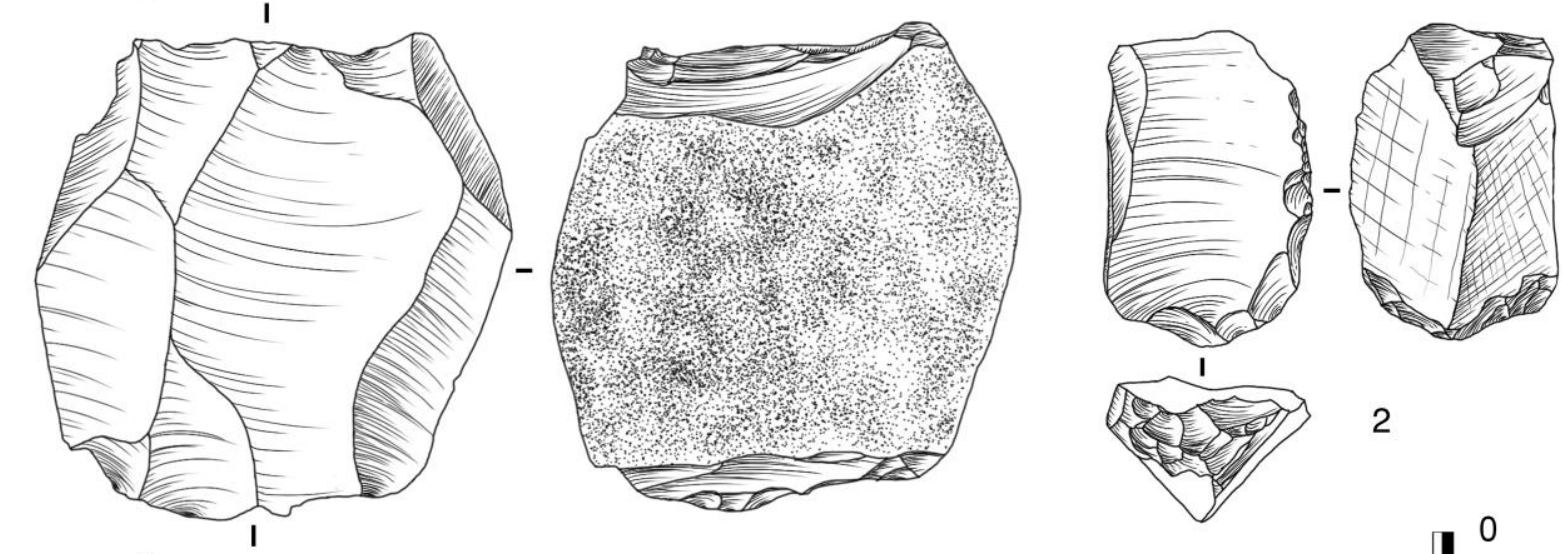

1

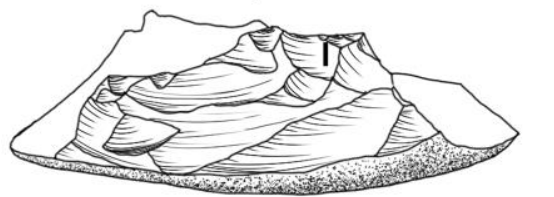

.

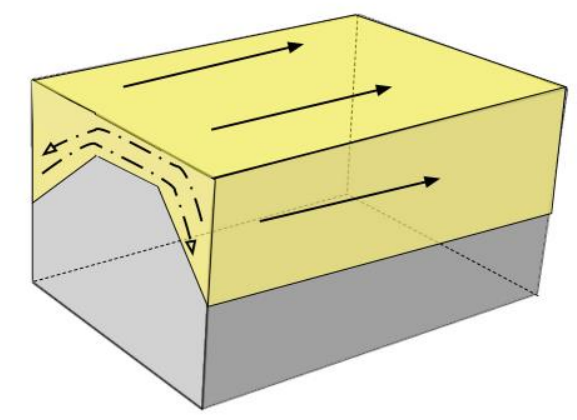

Partial configuration
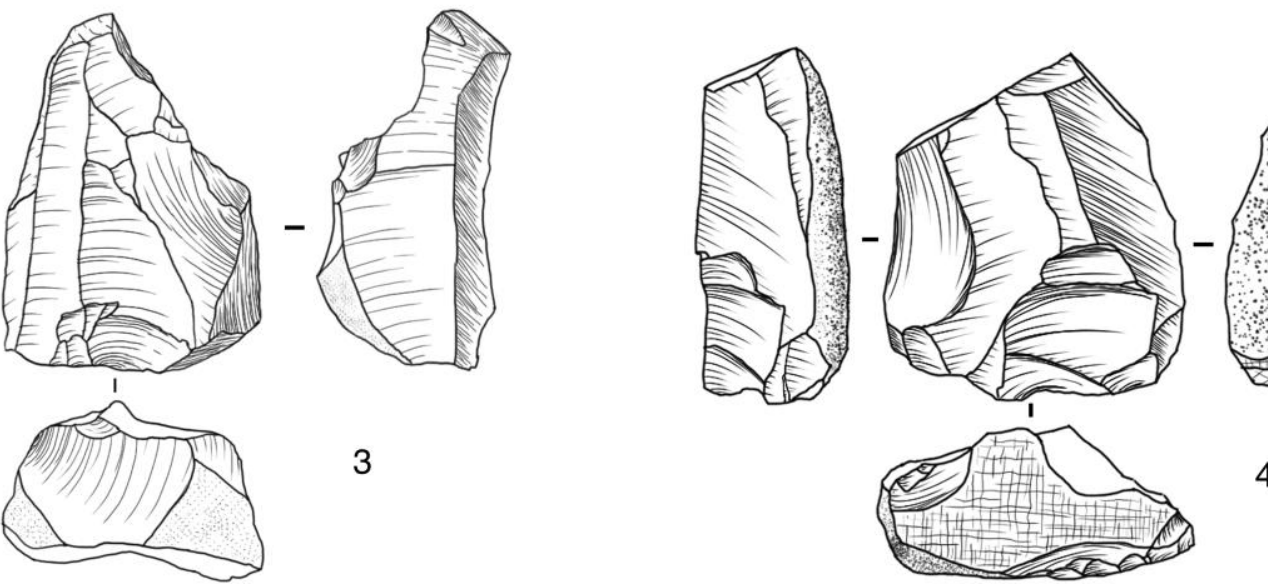

Figure 7. Riparo Tagliente. Lithic industries from the Intermediate Layers. (1) Levallois bidirectional core; (2) Levallois preferential core; $(3,4)$ Unidirectional system type 2 cores. 

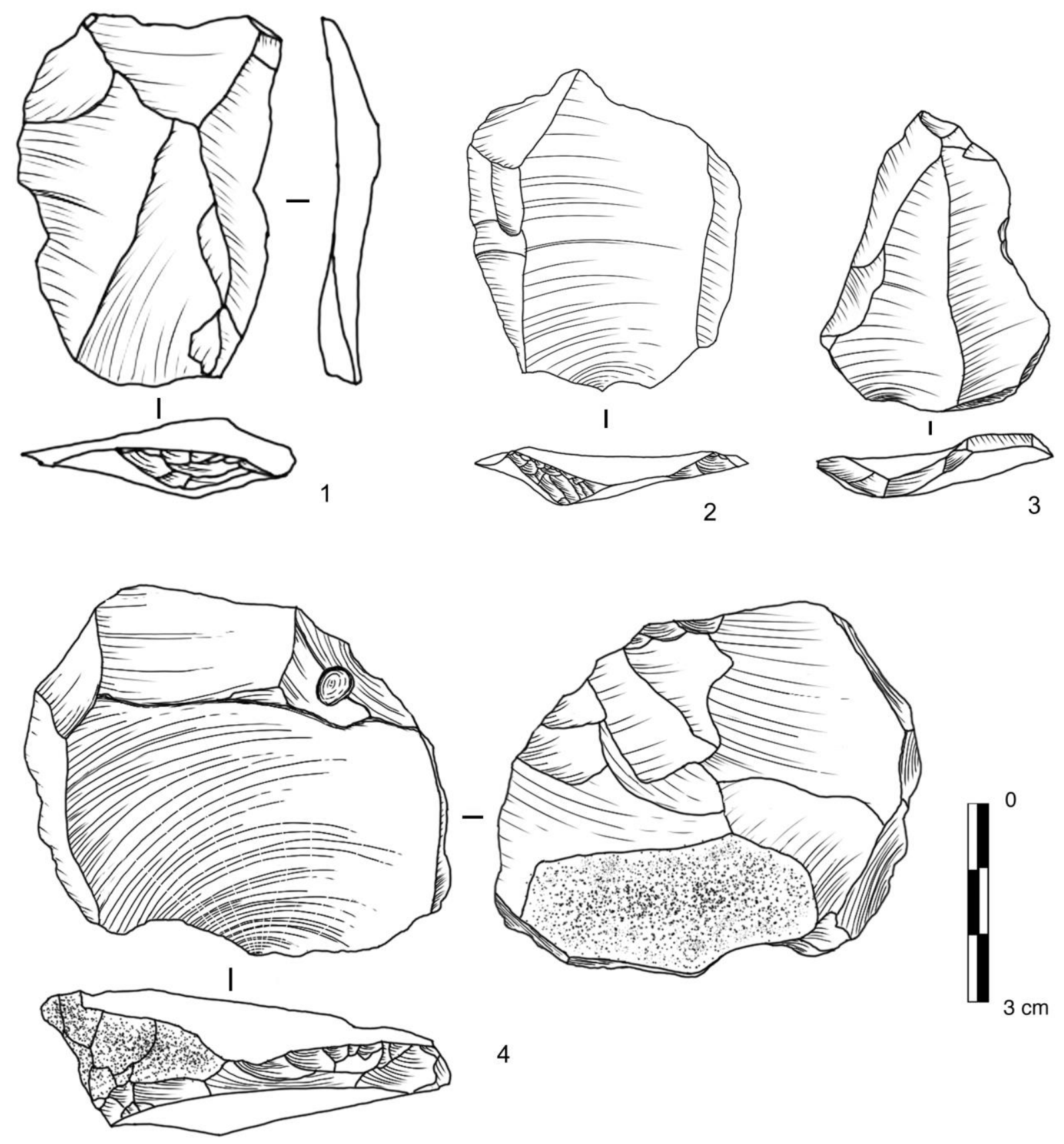

Figure 8. Riparo Tagliente. Lithic industries from the Upper Layers. (1) Levallois centripetal flake; (2) Levallois unidirectional flake; (3) Levallois convergent flake; (4) Levallois preferential core.

Table 3. Riparo Tagliente. Frequencies of retouched and unretouched pieces.

\begin{tabular}{lcccccc}
\hline & \multicolumn{2}{c}{ Lower layers } & \multicolumn{2}{c}{ Intermediate layers } & \multicolumn{2}{c}{ Upper layers } \\
& no. & $\mathbf{\%}$ & no. & \% & no. & \% \\
\hline Unretouched & 293 & 79,2 & 706 & 83,8 & 513 & 86,1 \\
Retouched & 77 & 20,8 & 136 & 16,2 & 83 & 13,9 \\
\hline Total & $\mathbf{3 7 0}$ & $\mathbf{1 0 0}$ & $\mathbf{8 4 2}$ & $\mathbf{1 0 0}$ & $\mathbf{5 9 6}$ & $\mathbf{1 0 0}$ \\
\hline
\end{tabular}


Table 4. Riparo Tagliente. Comparison between degree of retouch and débitage types. Abbreviations: U unretouched; L - low retouch; M - medium retouch; H - high retouch.

\begin{tabular}{lcccc|cccc|ccccc}
\hline & \multicolumn{3}{c}{ Lower layers } & \multicolumn{3}{|c|}{ Intermediate layers } & \multicolumn{3}{|c}{ Upper layers } \\
& $\mathbf{U}$ & $\mathbf{L}$ & $\mathbf{M}$ & $\mathbf{H}$ & $\mathbf{U}$ & $\mathbf{L}$ & $\mathbf{M}$ & $\mathbf{H}$ & $\mathbf{U}$ & $\mathbf{L}$ & $\mathbf{M}$ & $\mathbf{H}$ \\
\hline Levallois flakes & 28 & 17 & 2 & 0 & 122 & 18 & 9 & 0 & 52 & 4 & 3 & 0 \\
Centripetal flakes & 34 & 2 & 12 & 3 & 86 & 9 & 1 & 0 & 66 & 4 & 2 & 2 \\
Unidirectional flakes & 35 & 6 & 7 & 0 & 65 & 8 & 7 & 3 & 22 & 1 & 2 & 1 \\
Bidirectional flakes & 3 & 1 & 0 & 0 & 8 & 1 & 1 & 0 & 2 & 0 & 0 & 0 \\
Orthogonal flakes & 0 & 0 & 0 & 0 & 9 & 1 & 1 & 0 & 3 & 0 & 0 & 0 \\
Sub-convergent flakes & 5 & 0 & 0 & 0 & 11 & 3 & 0 & 0 & 3 & 1 & 0 & 1 \\
Convergent flakes & 3 & 0 & 0 & 0 & 6 & 0 & 0 & 1 & 1 & 0 & 0 & 0 \\
Debordant flakes & 19 & 0 & 0 & 0 & 44 & 3 & 1 & 3 & 0 & 0 & 0 & 1 \\
Pseudo-levallois & 0 & 0 & 0 & 0 & 1 & 1 & 0 & 0 & 3 & 0 & 1 & 0 \\
Kombewa & 14 & 0 & 0 & 0 & 29 & 2 & 0 & 0 & 9 & 1 & 0 & 0 \\
Levallois blades & 1 & 1 & 1 & 0 & 13 & 2 & 3 & 0 & 6 & 1 & 0 & 0 \\
Non Levallois blades & 25 & 0 & 3 & 0 & 43 & 10 & 3 & 0 & 43 & 3 & 2 & 0 \\
Crested blades & 1 & 0 & 0 & 0 & 0 & 0 & 0 & 0 & 0 & 0 & 0 & 0 \\
Striking platform flakes & 11 & 0 & 0 & 0 & 5 & 0 & 0 & 0 & 6 & 0 & 0 & 0 \\
Cortical flakes & 69 & 1 & 6 & $\mathbf{3}$ & 158 & 9 & 10 & 9 & 146 & 7 & 11 & 16 \\
Unspecific flakes & 45 & 2 & 5 & 5 & 106 & 4 & 7 & 6 & 151 & 4 & 3 & 12 \\
\hline Total & $\mathbf{2 9 3}$ & $\mathbf{3 0}$ & $\mathbf{3 6}$ & $\mathbf{1 1}$ & $\mathbf{7 0 6}$ & $\mathbf{7 1}$ & $\mathbf{4 3}$ & $\mathbf{2 2}$ & $\mathbf{5 1 3}$ & $\mathbf{2 6}$ & $\mathbf{2 4}$ & $\mathbf{3 3}$ \\
\hline
\end{tabular}

\subsection{Blade tools across the sequence}

Blade production is similar throughout the sequence with a slight increase in percentages in the Upper layers (Table 5). The blades can be described as being well preserved. Proximal fragments are the most numerous (Table 6).

Within the sequence different production systems can produce elongated blanks, both deriving from the unidirectional and bidirectional Levallois systems as well as from unidirectional non-Levallois systems (Unidirectional Type 1 and 2). Therefore the main aim of the study was to verify whether this variability was due to a predetermined intention to produce differentiated tools by using different reduction systems or whether this was only the result of opportunistic behaviour.

By observing the morphological characteristics of the blades and those of experimental representatives it was possible to distinguish two main blades categories: Levallois blades and non-Levallois blades. The blade fragments which could not be attributed to a specific category and blades with mixed characteristics that could have pertained to any category were placed in a third category termed 'undefined blades'.

The parameters taken into consideration when defining these categories were: types of platform, knapping surface angles, cutting edge angles, transversal cross-section, longitudinal profile, length-width ratio and width-thickness ratio.

Most of the blades fell in the 'undefined blade' category (Table 6). Levallois blades and non-Levallois blades are found in all layers in similar frequencies. From a morphometric point of view there is certain overlapping between the non-Levallois and Levallois productions in as far as the length-width ratio is concerned (Figure 10). 


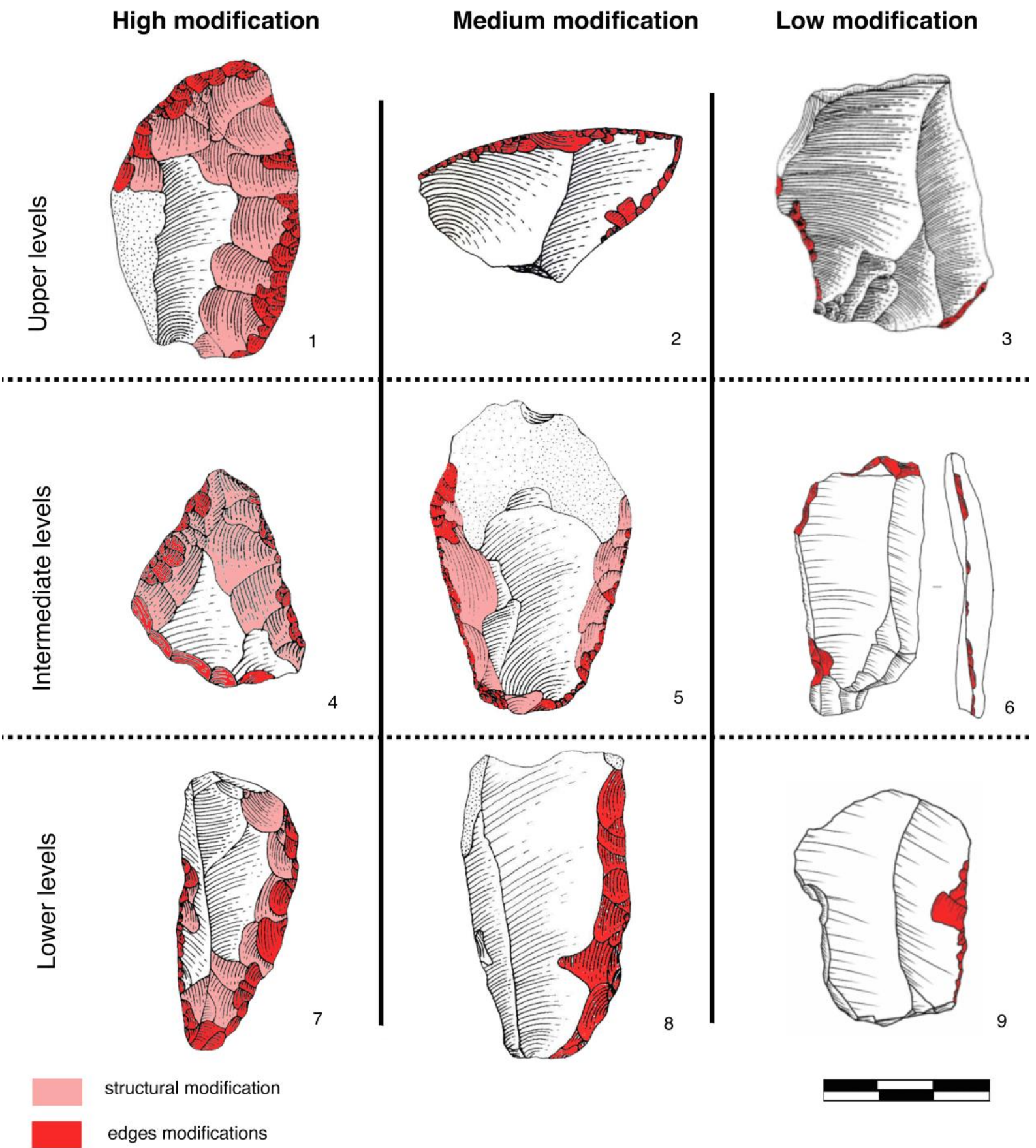

Figure 9. Riparo Tagliente retouched pieces. $(1,5)$ Scrapers on cortical flakes; $(4,7)$ Convergent scrapers on undefined flakes; $(2,3)$ Levallois retouched flakes; $(6,8,9)$ Unidirectional retouched flakes. (Drawings 1-3 and 4,5,7,8 modified after Arzarello 2003). The scale bar is $3 \mathrm{~cm}$ wide (3 sections of $1 \mathrm{~cm}$ each).

Table 5. Riparo Tagliente - Frequencies of blades and flakes. Cores and undetermined fragments are excluded from the count.

\begin{tabular}{lcccccc}
\hline & \multicolumn{2}{c}{ Lower layers } & \multicolumn{2}{c}{ Intermediate layers } & \multicolumn{2}{c}{ Upper layers } \\
& no. & $\%$ & no. & \% & no. & \% \\
\hline Flakes & 337 & 91,6 & 768 & 91,2 & 541 & 90,8 \\
Blades & 31 & 8,4 & 74 & 8,8 & 55 & 9,2 \\
\hline Total & $\mathbf{3 6 8}$ & $\mathbf{1 0 0}$ & $\mathbf{8 4 2}$ & $\mathbf{1 0 0}$ & $\mathbf{5 9 6}$ & $\mathbf{1 0 0}$ \\
\hline
\end{tabular}


Table 6. Riparo Tagliente. Blade classes and distinction between fragmented and whole pieces.

\begin{tabular}{|c|c|c|c|c|c|}
\hline & Layers & Lower layers & Intermediate layers & Upper layers & Total \\
\hline \multirow{7}{*}{ 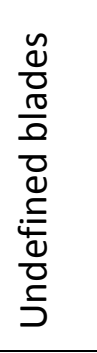 } & Whole & 14 & 17 & 18 & 49 \\
\hline & Apex absent & 0 & 1 & 0 & 1 \\
\hline & Platform absent & 0 & 1 & 1 & 2 \\
\hline & Distal fragment & 2 & 1 & 9 & 12 \\
\hline & Mesial fragment & 0 & 4 & 2 & 6 \\
\hline & Proximal fragment & 6 & 8 & 3 & 17 \\
\hline & Partial total & 22 & 32 & 33 & 87 \\
\hline \multirow{7}{*}{ 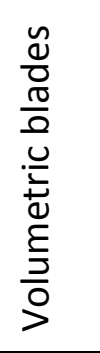 } & Whole & 5 & 16 & 5 & 26 \\
\hline & Apex absent & 0 & 1 & 1 & 2 \\
\hline & Platform absent & 1 & 1 & 0 & 2 \\
\hline & Distal fragment & 0 & 1 & 1 & 2 \\
\hline & Mesial fragment & 0 & 0 & 1 & 1 \\
\hline & Proximal fragment & 0 & 5 & 7 & 12 \\
\hline & Partial total & 6 & 24 & 15 & 45 \\
\hline \multirow{7}{*}{$\begin{array}{l}\frac{y}{0} \\
\frac{0}{0} \\
\frac{\pi}{0} \\
\frac{n}{0} \\
\overline{\overline{0}} \\
\bar{\Xi}\end{array}$} & Whole & 2 & 13 & 3 & 18 \\
\hline & Apex absent & 1 & 2 & 0 & 3 \\
\hline & Platform absent & 0 & 0 & 1 & 1 \\
\hline & Distal fragment & 0 & 1 & 1 & 2 \\
\hline & Mesial fragment & 0 & 0 & 0 & 0 \\
\hline & Proximal fragment & 0 & 2 & 2 & 4 \\
\hline & Partial total & 3 & 18 & 7 & 28 \\
\hline Total & 31 & 74 & 55 & 160 & \\
\hline
\end{tabular}

ratio lenght - width: 49 elements

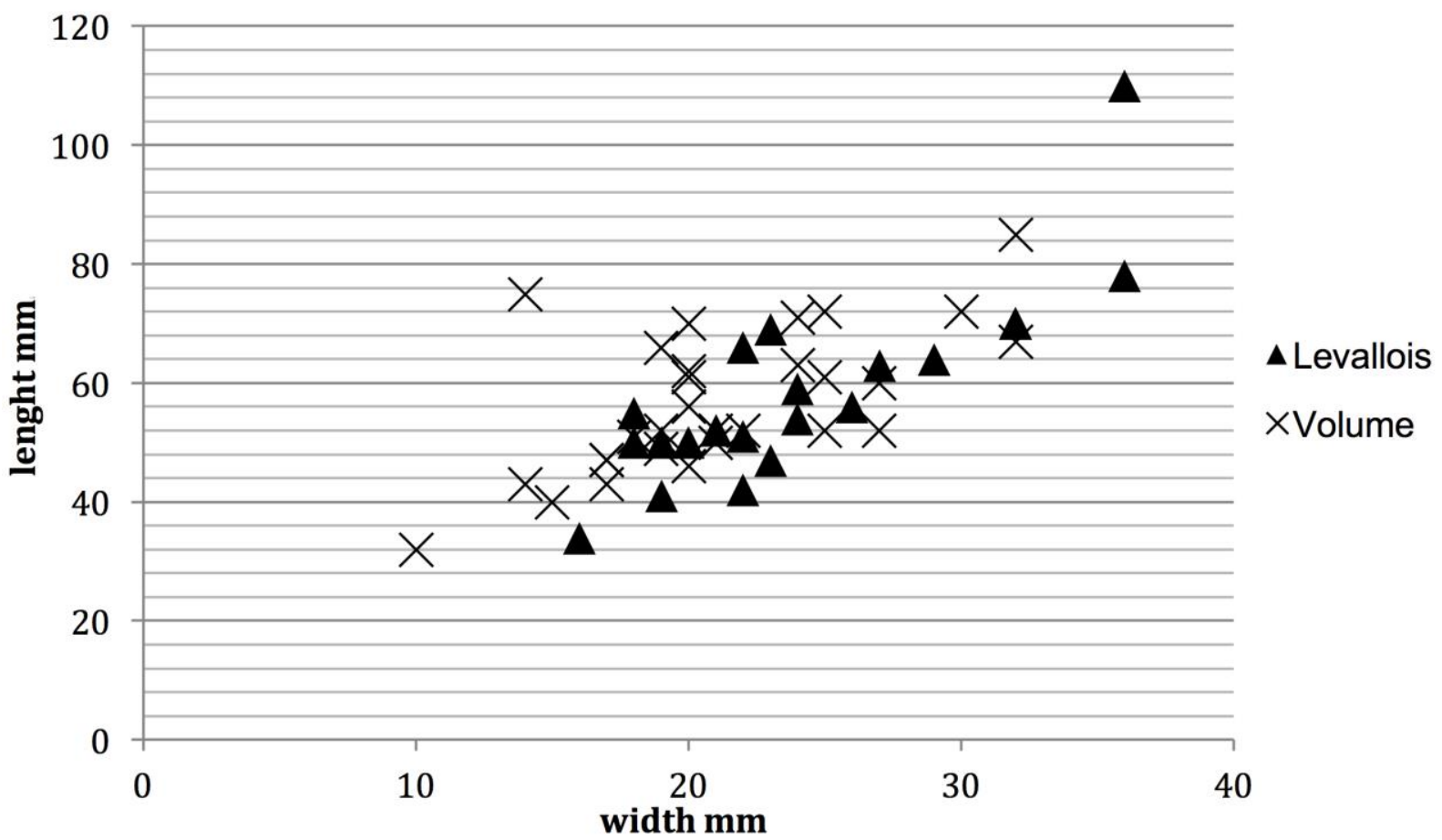

Figure 10. Riparo Tagliente. Levallois and Non-Levallois blade length-width ratios. 
Conversely a significant difference is evident in their width-thickness ratios (Figure 11). This difference is also noticeable when we compare the angle of the cutting edges. In the Levallois blades the opening of the angles are concentrated between $10^{\circ}$ and $35^{\circ}$, while the non-Levallois blades show wider angles of the cutting edges, ranging between $35^{\circ}$ and $55^{\circ}$ (Figure 12).

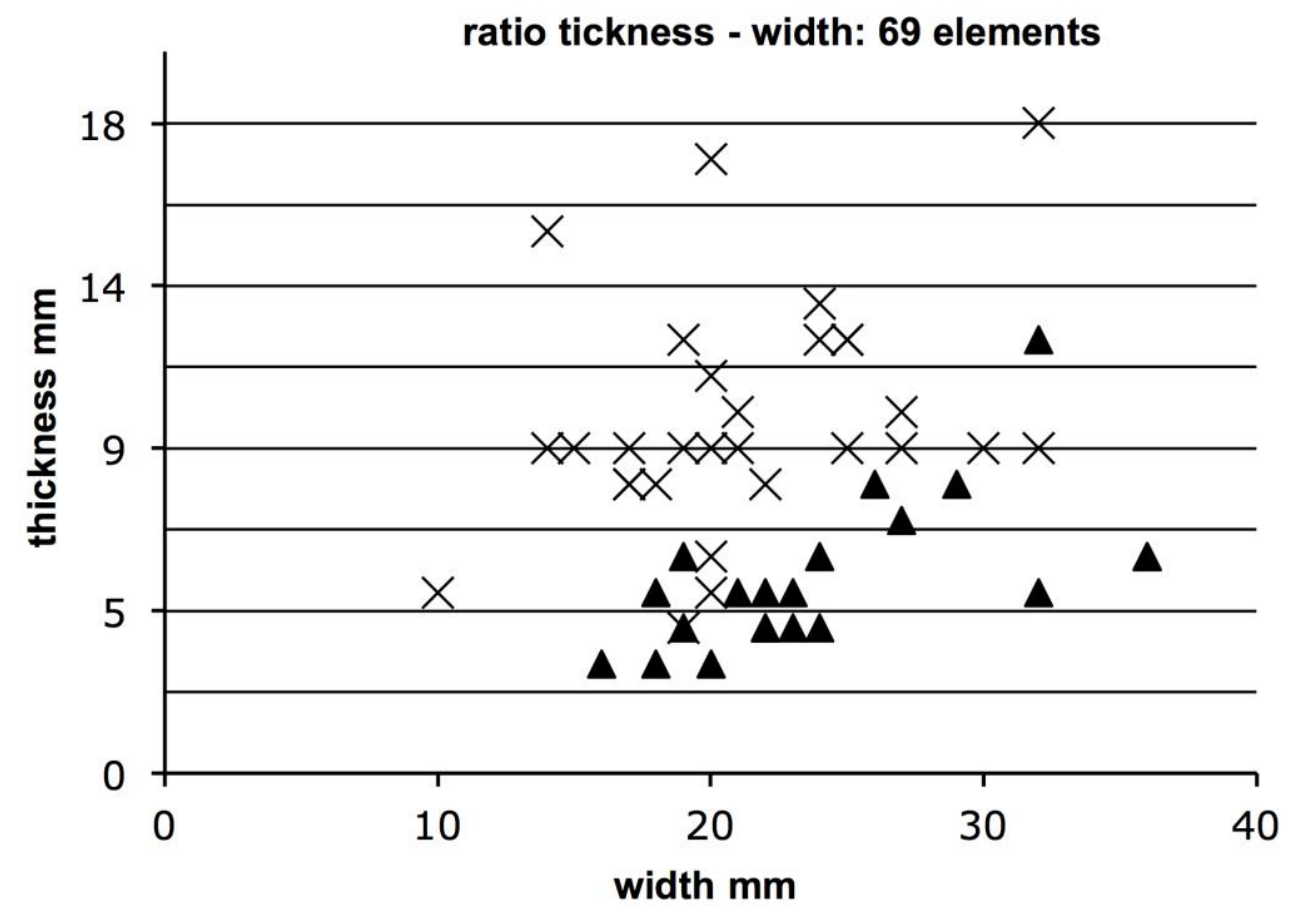

$\Delta$ Levallois $\times$ Volume

Figure 11. Riparo Tagliente. Levallois and Non-Levallois blade thickness-width ratios.

Both for the Levallois and non-Levallois productions, six techno-functional categories were observed, all based on the morphological structure and the organization of the cutting and non-cutting edges (Figure 13). Only completely intact blades were analysed; minimally fractured pieces were also excluded.

In general, we can observe how blade production at Riparo Tagliente focused on the production of objects with differentiated techno-functional characteristics rather than the making of a mono-tool (Figure 14).

By comparing the classes of blade we can see how blades with a peripheral cutting edge (S1 Type) are attributed mainly to Levallois blades. On the contrary, debordant blades (S3, S4 type) are more frequent among the Non-Levallois blades. Convergent blades (P1 type, P2 type) are rare in both categories (Table 7). The undefined blade category does not show any specific tendency except for the scarce presence of convergent blades, as was the case in the Levallois and non-Levallois blades. 
Levallois blades: 23 pieces

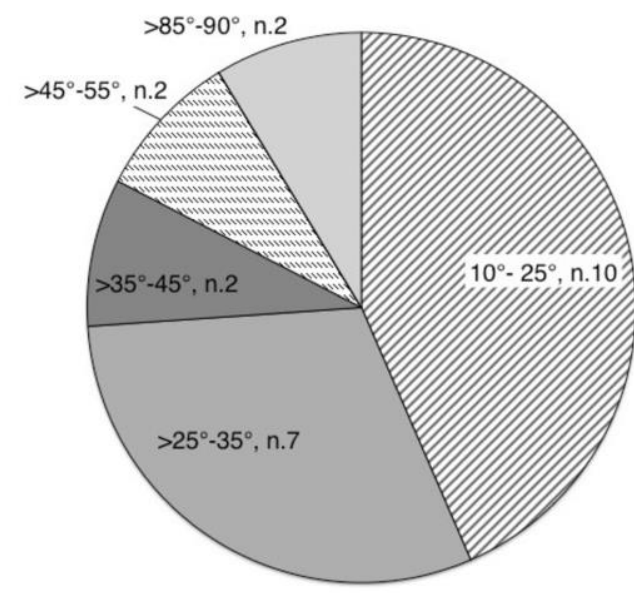

left edge

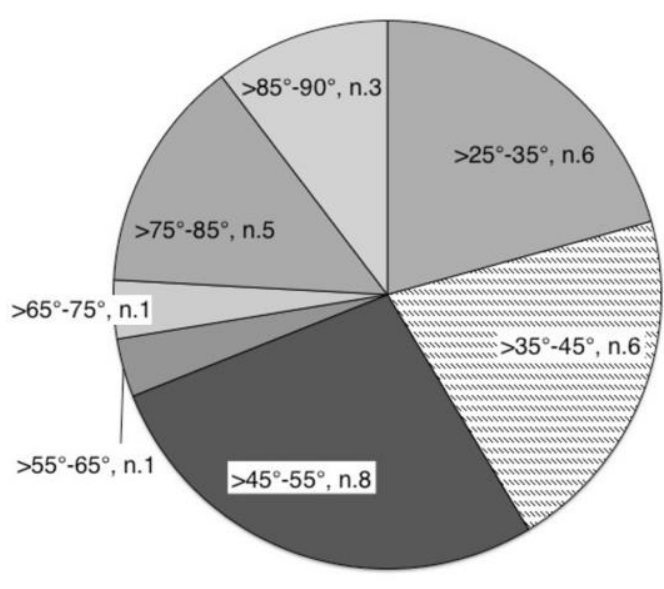

left edge

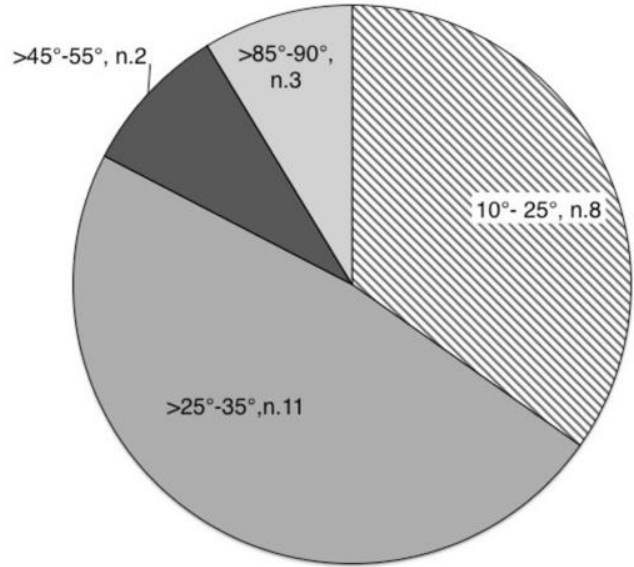

distal edge

Volumetric blades: 29 pieces

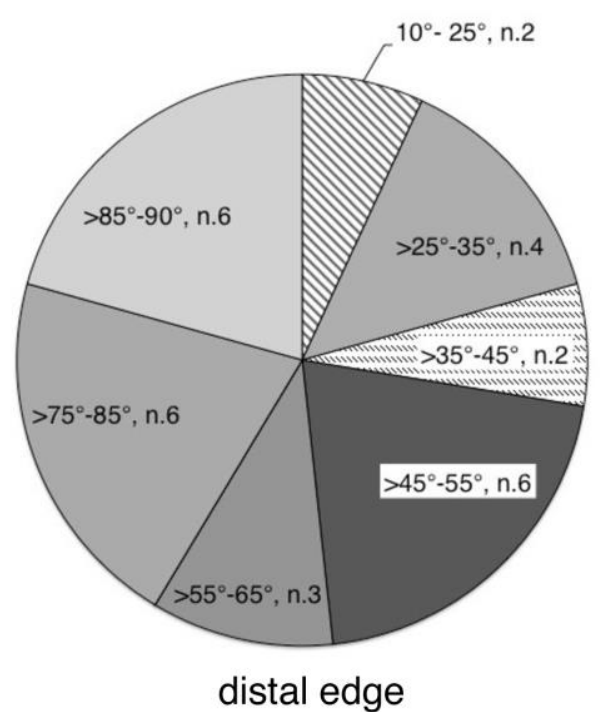

Figure 12. Riparo Tagliente. Cutting edge angle degrees of Levallois and Non-Levallois blades.
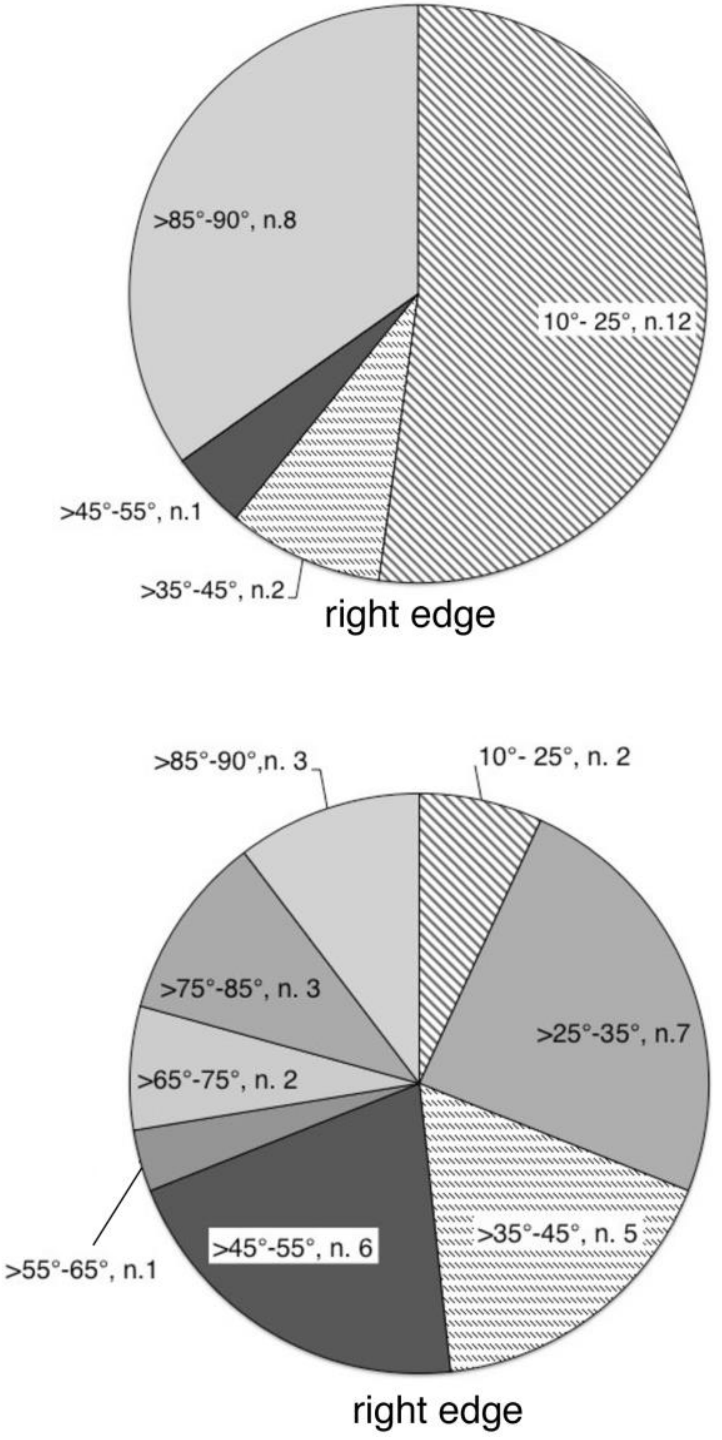

Journal of Lithic Studies (2017) vol. 4, nr. 1, p. xx-xx 


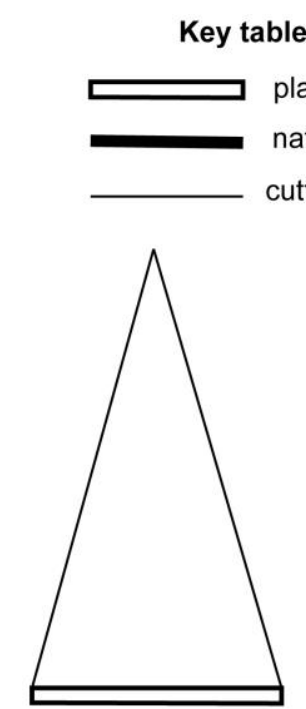

P1

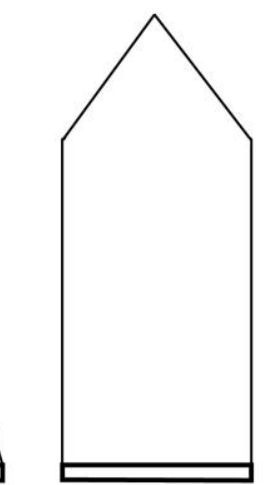

P2

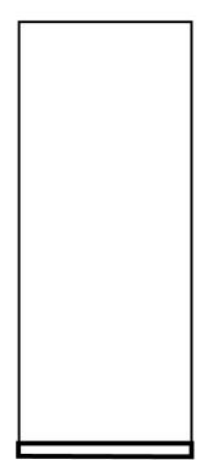

S1

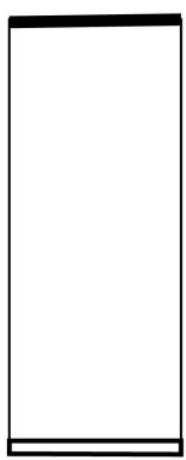

S2

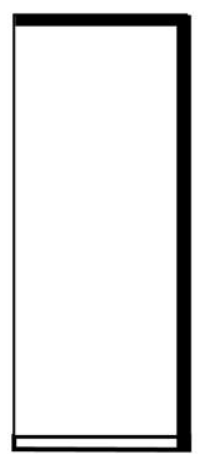

S3

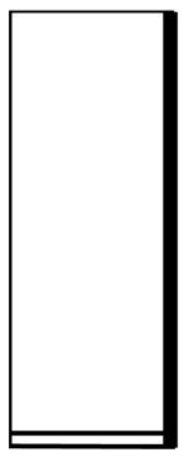

S4

Figure 13. Riparo Tagliente. Blade types.

Table 7. Riparo Tagliente. Blade types.

\begin{tabular}{|c|c|c|c|c|}
\hline & & Lower layers & Intermediate layers & Upper layers \\
\hline \multirow{7}{*}{ 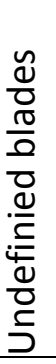 } & P1 type (convergent edges) & 1 & - & 3 \\
\hline & P2 type (parallel edges) & - & 3 & 2 \\
\hline & S1 pheriferal cutting edge & 3 & 4 & 6 \\
\hline & S2 parallel cutting edge & 6 & 5 & 2 \\
\hline & S3 single cutting edge & 3 & 3 & 3 \\
\hline & S4 orthogonal cutting edge & 1 & 2 & 2 \\
\hline & Partial total & 14 & 17 & 18 \\
\hline \multirow{7}{*}{ 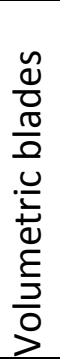 } & P1 type (convergent edges) & 1 & - & - \\
\hline & P2 type (parallel edges) & 1 & 2 & 2 \\
\hline & S1 pheriferal cutting edge & - & 3 & - \\
\hline & S2 parallel cutting edge & - & 5 & 1 \\
\hline & S3 single cutting edge & - & 2 & - \\
\hline & S4 orthogonal cutting edge & 3 & 4 & 2 \\
\hline & Partial total & 5 & 16 & 5 \\
\hline \multirow{8}{*}{ 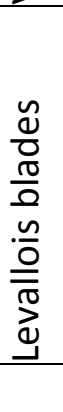 } & P1 type (convergent edges) & - & - & 1 \\
\hline & P2 type (parallel edges) & - & 3 & - \\
\hline & S1 pheriferal cutting edge & 1 & 7 & 2 \\
\hline & S2 parallel cutting edge & 1 & - & - \\
\hline & S3 single cutting edge & - & 3 & - \\
\hline & S4 orthogonal cutting edge & - & - & - \\
\hline & Partial total & 2 & 13 & 3 \\
\hline & Total & 21 & 43 & 27 \\
\hline
\end{tabular}



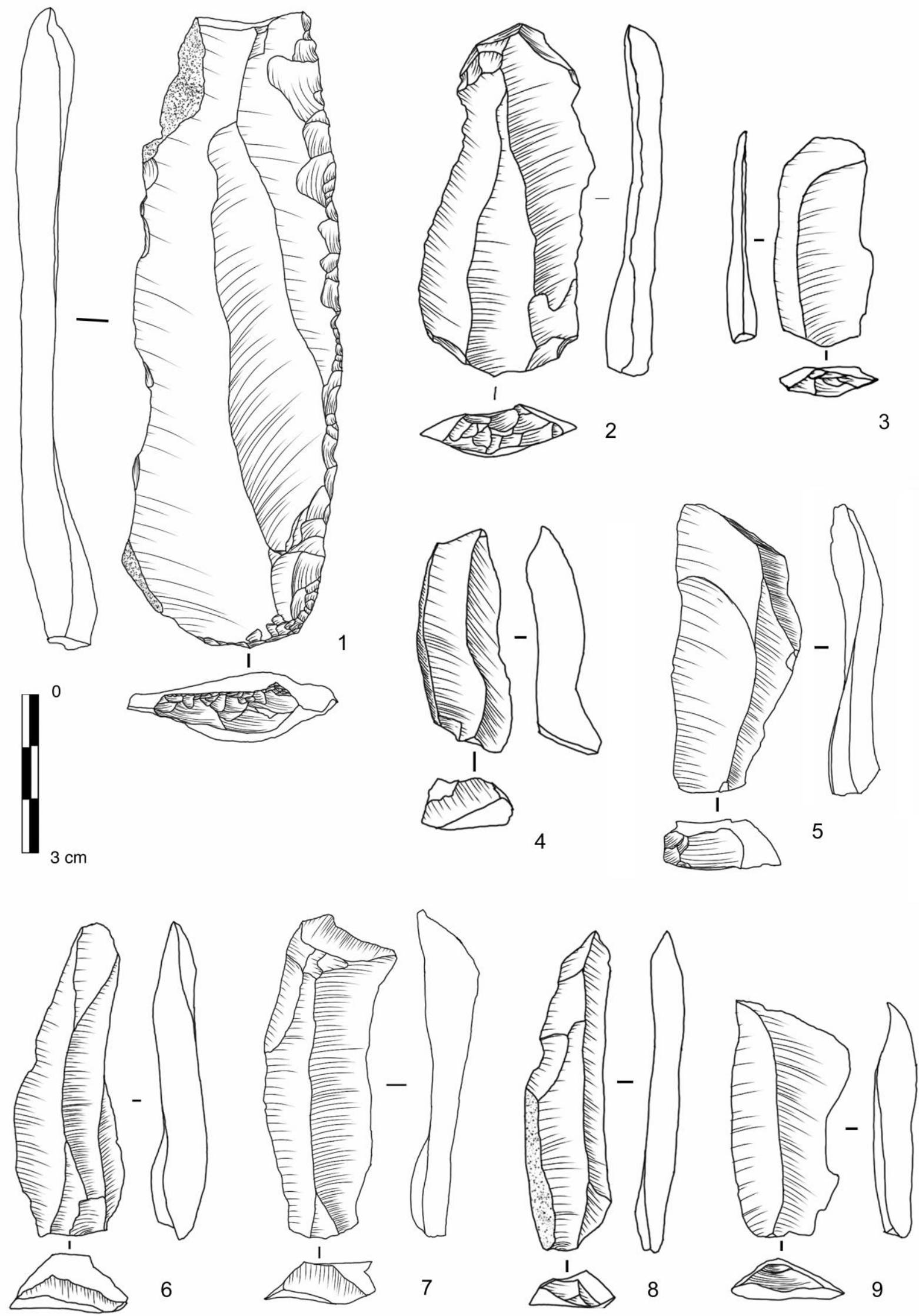

Figure 14. Blade production at Riparo Tagliente. (1) 'S1 type' Levallois blade from the Lower layers; (2) 'S2 type' Levallois blade from the Intermediate layers; (3) 'S1 type' Levallois elongated flake from the Upper layers; (4) 'S4 type' non-Levallois blade from the Lower layers; (5) 'S3 type' non-Levallois blade from the Intermediate layers; $(6,7)$ 'S1 type' non-Levallois blades from the Upper layers; (8) 'P1 and P2 type' non-Levallois blades from the Upper layers. 


\section{Discussion and conclusion}

Despite the apparent substantial homogeneity of the Riparo Tagliente sequence, some differences can be observed in the reduction systems used. The main characteristics, common to the whole sequence, are the use of the Levallois concept and the production of elongated blanks. Other common features such as the presence, even though sporadic, of the Discoid and SSDA systems are shared by the Lower and Intermediate layers. This homogeneity, which is evident in the end-products, masks the presence of some differences, these mainly visible in the cores.

The greatest variability in the reduction systems used can be observed in the Lower layers (Figure 15). In the Intermediate and Upper layers, the fall in the number of reduction systems is replaced by an increase of the variability of the Levallois concept, which is expressed by means of the centripetal method as well as the convergent, bidirectional and preferential methods (Figure 15).
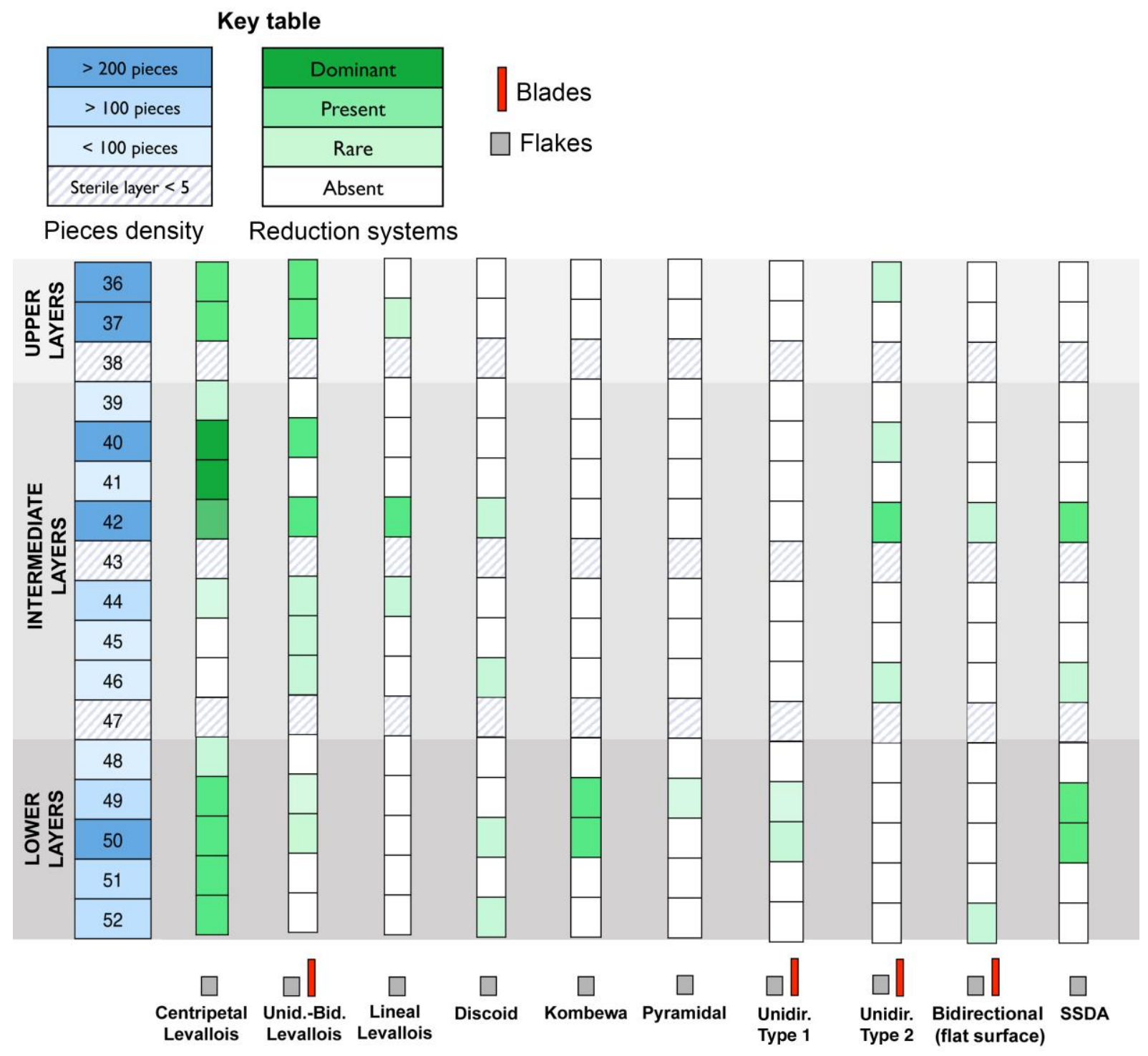

Figure 15. Riparo Tagliente. Frequencies of the reduction systems.

The retouched pieces only reveal minimal modifications of the cutting edges without altering the morphology of the flake nor the blade. Cortical flakes are the most affected and in this case underwent significant modification, while the products deriving from the main 
débitage phases were seldom retouched. This can be linked to the anticipation of the variability of the end products for flakes as well as blades already preconceived in the production systems. This aspect emphasizes the substantial difference with the more standardized blade productions of the Upper Paleolithic where differentiation of tools is usually mostly achieved during the retouching phase. Based on our data, at Riparo Tagliente, Levallois and non-Levallois reduction systems coexisted producing elongated blanks, different in their morphological and technological characteristics as a direct result of the different reduction systems used to obtain them. Both reduction systems are aimed at producing blades and flakes rather than blades in a systematic way. This differentiation in production can be observed in the Levallois unidirectional and bidirectional end products as well as in the unidirectional Type 1 reduction system.

By observing the Riparo Tagliente sequence within the context of the Italian peninsula it is therefore possible to make a number of general observations (Figure 16).

The first observation is that the blade phenomenon in the Italian peninsula appeared at some point between MIS 4 and the beginning of MIS 3 and therefore later than in the south of France where blade production is first recorded as early as MIS 5 (Figure 16). The data from Riparo Tagliente fit will within this framework.

The second observation is that, as far as we know, there is no trace of local nor internal evolution. In fact, blade production seems to appear 'simultaneously' from north to south in the Italian peninsula and is always associated to other types of reduction systems of which the Levallois is the most common. (Figure 16).

As already noted for the rest of Europe, the production of blades did not entail a particular raw material preference. Blades were made from all types of raw materials (flint, chert, limestone, quartzite) and their different forms (pebbles, nodules, slabs, core flakes). Various reduction systems were used in the production of blades. Blades can be produced exclusively by means of a Levallois concept, as in the cases of Grotta di Castelcivita (Gambassini 1997), Riparo del Poggio (Caramia \& Gambassini 2006), Barma Grande (Yamada 1997), and Riparo Mochi (Grimaldi \& Santaniello 2014; Yamada 2004), or by 'volumetric' reduction systems, as is the case at the sites of Santa Croce (Arrighi et al. 2009), Grotta Reali (Arzarello et al. 2004; Peretto 2012), and Grotta del Cavallo (Carmignani 2010). Occasionally the two systems were used together as has been noted at Riparo dell'Oscurusciuto (Villa et al. 2009) and Riparo Tagliente (Arzarello \& Peretto 2004; 2005).

In short we can observe how during the MIS 4 and MIS 3 there is widespread production of blades produced by means of original knapping systems or as in the case of the Levallois by a readjustment of this concept oriented towards the production of elongated products.

Given the current state of knowledge there is still much to be learnt concerning the causes of this technological change.

Middle Paleolithic blade productions cannot be considered as monolithic entities.

This 'non universal' phenomenon contrasts with other types of production systems such as the Levallois or the Discoid system, with which it coexisted and which contrastingly show a greater geographic diffusion and chronological continuity.

Understanding the role of blade production during Middle Paleolithic requires a systematic approach, which takes into account both the techno-functional aims and the evolution of the reduction systems.

Further research should be carried out on the following two issues:

- Concerning the appearance of blade production, are the diachronic differences noted between northern and southern Europe another case of a convergence phenomenon?

- Can we trace the origins of the Italian peninsula blade phenomenon in the oldest evidence found in southern France? 


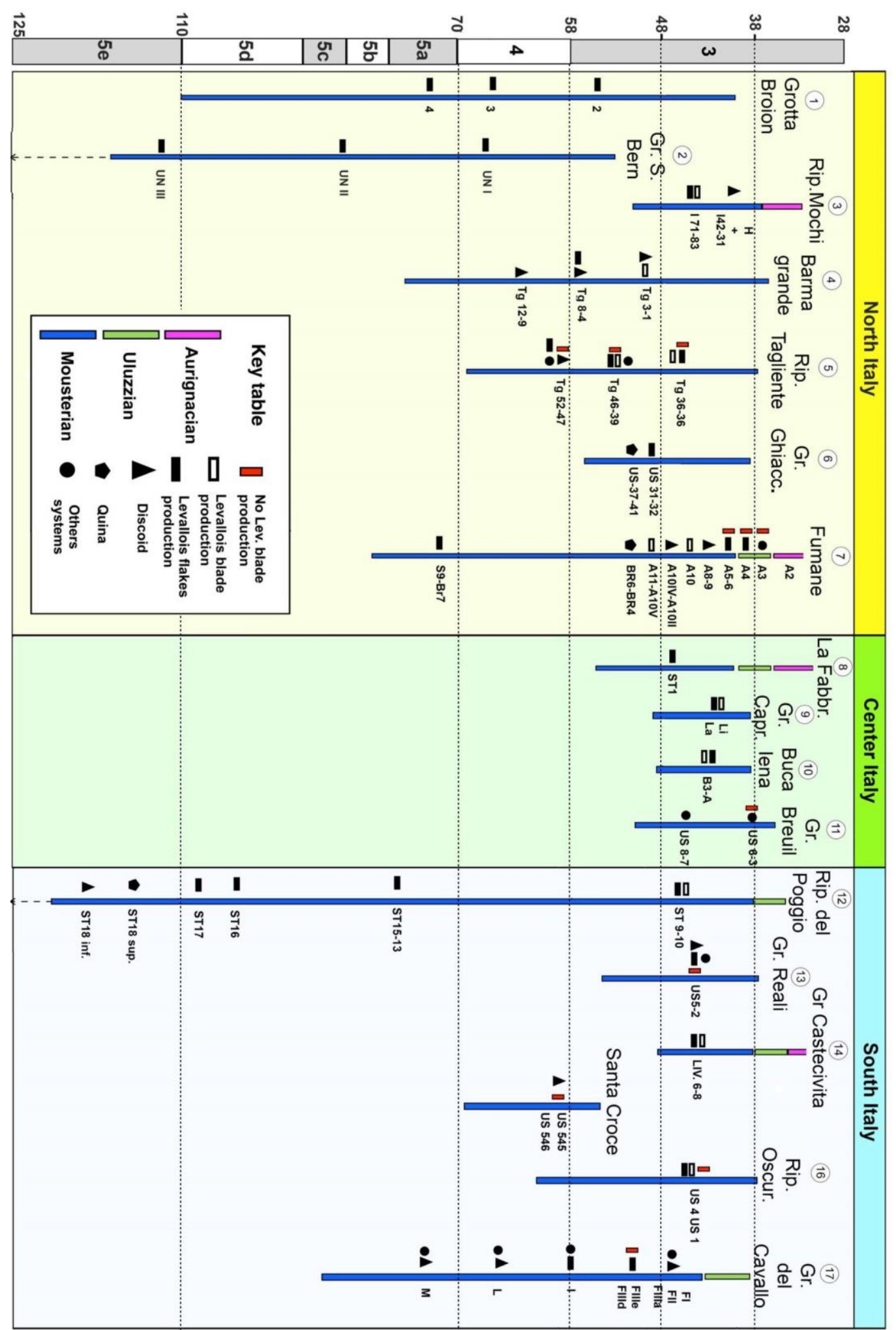

Figure 16. Reduction systems in the main Middle Paleolithic sites from MIS 5 to MIS 3 in the Italian peninsula. (1) Grotta del Broion (Peresani \& Porraz 2004); (2) Grotta San Bernardino (Peresani 1995; 1996); (3) Riparo Mochi (Grimaldi \& Santaniello 2014; Yamada 2004); (4) Barma Grande (Yamada 1997); (5) Riparo Tagliente (Arzarello \& Peretto 2004; 2005); (6) Grotta Ghiacciaia (Bertola et al. 1999); (7) Fumane (Peresani 2012); (8) Grotta La Fabbrica (Dini et al. 2007); (9) Grotta del Capriolo (Dini \& Koehler 2009); (10) Buca della Iena (Dini \& Koehler 2009); (11) Grotta Breuil (Lemorini 2000; Grimaldi 1996); (12) Riparo del Poggio (Caramia \& Gambassini 2006); (13) Grotta Reali (Peretto 2012); (14) Grotta di Castelcivita (Gambassini 1997); (15) Santa Croce (Arrighi et al. 2009); (16) Riparo Oscurusciuto (Boscato et al. 2011); (17) Grotta del Cavallo (Carmignani 2010; Sarti et al. in press). 
In order to provide answers to both these questions micro and macro regional comparisons of the various blade productions are urgently required in order to understand the blade phenomenon in both its wider and more local geographical context.

\section{Acknowledgements}

The present research is supported by a European Union Erasmus Mundus Programme scholarship, 'International Doctorate in the Quaternary and Prehistory' (IDQP).

I am especially grateful to Marie-Hélène Moncel for her insightful comments and suggestions, and for help with the revision of this paper. I would also like to thank Robert Sala Ramos for his helpful and constructive remarks when planning this project, and Marta Arzarello for helping me to better understand Riparo Tagliente's stratigraphy.

Finally, I am deeply grateful to the organizers of this conference, Sara Cura and Éric Boëda, in which I have had the honour to participate.

\section{References}

Adam, A. 1991, Le gisement paléolithique moyen du Rissori à Masnuy-Saint-Jean (Hainaut, Belgique): Premiers résultats. In: Paléolithique et Mésolithique du Nord de la France, Nouvelles recherches II (Tuffreau, A., Ed.), Publications du CERP Vol. 3, Centre d'Études et de Recherches Préhistoriques (CERP), Université des Sciences et Technologies de Lille, Villeneuve d'Ascq: p. 41-52. (in French) (The Middle Paleolithic site of Rissori à Masnuy-Saint-Jean (Hainaut, Belge): First results))

Adam, A., \& Tuffreau, A. 1973, Le gisement paléolithique ancien du Rissori, à MasnuySaint-Jean (Hainaut, Belgique). Bulletin de la Société Préhistorique Française, 70(1): 293-310. (in French) (The ancient Paleolithic site of Rissori at Masnuy-Saint-Jean (Hainaut, Belgique)) doi:10.3406/bspf.1973.4377

Ameloot-Van der Heijden, N. 1993, L'industrie laminaire du niveau C.A. du gisement paléolithique moyen de Riencourt-lès-Bapaume (Pas-de-Calais). Bulletin de la Société Préhistorique Française, 90(5): 324-327. (in French) (The Middle Paleolithic blade industries of the level C.A. of Riencourt-lès-Bapaume (Pas-de-Calais)) doi:10.3406/bspf.1993.9641

Arrighi, S., Freguglia, M., Ranaldo, F., \& Ronchitelli, A. 2009, Production and use in the lithic industry of the Mousterian in Santa Croce (Bisceglie, Italy). Human Evolution, 24(2): 91-106.

Arzarello, M. 2003, Contributo allo studio del comportamento tecno-economico dell'uomo di Neandertal: L'industria litica della serie musteriana del Riparo Tagliente (Stallavena di Grezzana, Verona, Italia). Ph.D. thesis, Università di Ferrara, Ferrara, 270 p. (in Italian) (Contribution to the study of the techno-economic behavior of Neanderthal man: The lithic industry of the Mousterian series of Riparo Tagliente (Stallavena di Grezzana, Verona, Italy))

Arzarello, M., Berardinelli, L., Minelli, A., Pavia, M., Rufo, E., Sala, B., Thun Hohenstein, U., \& Peretto, C. 2004, Il sito paleolitico medio di Grotta Reali (Rocchetta al Volturno, Molise, Italia). Rivista di Scienze Preistoriche, 54: 249-269. (in Italian) (The Middle Paleolithic site of Grotta Reali, (Rocchetta al Volturno, Molise, Italy))

Arzarello, M., Bertola, S., Fontana, F., Guerreschi, A., Thun-Hohenstein, U., Liagre, J., Peretto, C., \& Rocci Ris, A. 2007, Aires d'approvisionnement en matières lithiques et 
en ressources alimentaires dans les niveaux moustériens et epigravettiens de l'Abri Tagliente (Verone, Italie): Une dimension "locale". In: Aires d'approvisionnement en matières premières et aires d'approvisionnement en ressources alimentaires (Moncel, M.-H., Moigne, A.-M., Arzarello, M., \& Peretto, C., Eds.), BAR International Series Vol. 1725, Archaeopress, Oxford: p. 161-169. (in French) (Raw material and food resources procurement in the Mousterian and Epigravettian levels of Riparo Tagliente, (Verona Italy): A local dimension)

Arzarello, M., \& Peretto, C. 2004, L'industrie lithique moustérienne (“Tagli 40-42”) du Riparo Tagliente (Verone, Italie). In: Acts of the XIVth UISPP Congress, University of Liège, Belgium, 2-8 September 200110 Section 5: Le Paléolithique Moyen/The Middle Palaeolithic General sessions and posters (Le Secrétariat du Congrès, Ed.), British Archeological Reports International Series Vol. 1239, Archaeopress, Oxford: p. 169175. (in French) (The Mousterian lithic industries "Layers 40-42" of Riparo Tagliente, (Verona, Italy))

Arzarello, M., \& Peretto, C. 2005, Nouvelles données sur les caractéristiques et l'évolution tecno-économique de l'industrie moustérienne du Riparo Tagliente (Verone, Italie). In: Actes du Colloque International "Données recents sur les modalités de peuplement et sur le cadre chronostratigraphique, géologique et paléogeographique des industries du Paléolithique inferieur et moyen en Europe" (Rennes, 22-25 septembre 2003) (Molines, N., Monnier, J.-L., \& Moncel, M.-H., Eds.), British Archeological Reports International Series Vol. 1364, Archaeopress, Oxford: p. 281-289. (in French) (New data on the evolution and the techno-economical features of the lithic industries of Riparo Tagliente (Verona, Italy))

Barkai, R., Gopher, A., \& Shimelmitz, R. 2005, Middle Pleistocene Blade Production in the Levant: An Amudian assemblage from Qesem Cave, Israel. Eurasian Prehistory, 3: 9-74.

Bartolomei, G., Broglio, A., Cattani, L., Cremaschi, M., Guerreschi, A., Mantovani, E., Peretto, C., \& Sala, B. 1982, I depositi würmiani del Riparo Tagliente. Annali dell'Università di Ferrara, Sezione XV, 3(4): 51-105. (in Italian) (The Wurmian deposits of Riparo Tagliente)

Bartolomei, G., Broglio, A., Cattani, L., Cremaschi, M., Guerreschi, A., Leonardi, P., \& Peretto, C. 1984, Paleolitico e Mesolitico. In: Il Veneto nell'Antichità. Preistoria e Protostoria, Vol. 2 (Aspes, A., Ed.), Banca Popolare di Verona, Verona: p. 167-319. (in Italian) (Paleolithic and Mesolithic)

Bertola, S., Peresani, M., Peretto, C., \& Thun-Hohenstein, U. 1999, Le site paléolithique moyen de la Grotta della Ghiacciaia (Préalpes de Vénétie, Italie du Nord). L'Anthropologie, 103(3): 377-390. (in French) (The Middle Paleolithic site of Grotta Ghiacciaia (Venetian pre-Alps, nothern Italy))

Blaser, F., Bourguignon, L., Sellami, F., \& Rios Garaizar, J. 2012, Une série lithique à composante laminaire dans le Paléolithique moyen du Sud-Ouest de la France: le site de Cantalouette 4 (Creysse, Dordogne, France). Bulletin de la Société Préhistorique Française, 109(1): 5-33. (in French) (A blade industries in the Middle Paleolithic of Southern France: The site of Cantalouette 4, (Creysse, Dordogne, France))

Boëda, E. 1988, Analyse technologique du débitage du niveau IIA. In: Le gisement paléolithique moyen de Biache-Saint-Vaast (Pas-de-Calais), Stratigraphie, Environnement, Études Archéologiques (1ere partie), Vol. 1 (Tuffreau, A., \& Sommé, 
J., Eds.) Mémoire de la Societé Préhistorique Française Vol. 21, Conseil general du Pas-De-Calais, Arras: p.185-214. (in French) (Technological analysis of the level IIA)

Boëda, E. 1990, De la surface au volume. Analyse des conceptions des débitages Levallois et laminaire. In: Paléolithique moyen récent et Paléolithique supérieur ancien en Europe. Ruptures et transitions: Examen critique des documents archéologiques (Farizy, C., Ed.), Mémoire du Musée de Préhistoire d'Ile de, Association Pour la Promotion de la Recherche Archéologique en Ile-de-France, Nemours: p. 63-68. (in French) (From de surface to the volume. Study of the concepts of the Levallois and blade reduction strategies)

Boëda E. 1991, Approche de la variabilité des systèmes de production lithique des industries du Paléolithique inférieur et moyen: Chronique d'une variabilité attendue. Technique et Culture, 17(18): 37-79. (in French) (Reduction strategies variability of the Lower and Middle Paleolithic lithic industries: Report of an expected variability)

Boëda E. 1993, Le débitage discoïde et le débitage Levallois récurrent centripète. Bulletin de la Société Préhistorique Française, 90: 392-404. (in French) (The centripetal Discoid and Levallois reduction strategies)

Boëda, E. 1994, Le concept Levallois: Variabilité des méthodes. Centre National de la Recherche Scientifique éditions, Paris, 280 p. (in French) (The Levallois concept: Methods variability)

Boëda, E., Hou, Y.M., Forestier, H., Sarel, J., \& Wang, H.M. 2013, Levallois and nonLevallois blade production at Shuidonggou in Ningxia, North China. Quaternary International, 295: 191-203. doi:10.1016/j.quaint.2012.07.020

Bordes, F. 1977, Que sont le Pré-Aurignacien et le Iabroudien? In: Eretz Israel (Arensburg, B., \& Bar Yosef, O., Eds.), Moshé Stekelis Memorial Volume. Vol. 13, Israel Exploration Society, Jerusalem: p. 49-55. (in French) (Who are the Preaurignacian and the Yabrudian?) URL: http://www.jstor.org/stable/23618740

Boscato, P., Gambassini, P., Ranaldo, F., \& Ronchitelli, A. 2011, Management of Paleoenvironmental Resources and Exploitation of Raw Materials at the Middle Paleolithic Site of Oscurusciuto (Ginosa, Southern Italy): Units 1 and 4. In: Neanderthal Lifeways, Subsistence and Technology. One Hundred Fifty Years of Neanderthal Study (Conard, N.J., \& Richter, J. Eds.), Springer, New York: p. 87-96. doi:10.1007/978-94007-0415-2_9

Bosinski, G. 1986, Chronostratigraphie du Paléolithique inférieur et moyen en Rhénanie. In: Chronostratigraphie et faciès culturels du Paléolithique inférieur et moyen dans l'Europe du Nord Ouest "Actes du 22ème congrès préhistorique de France, Lille-Mons, 2-7 sept. 1984" (Tuffreau, A., \& Sommé, J., Eds.), Supplément du Bulletin de Association Française pour l'Étude du Quaternaire Vol. 26, Association Française pour l'Étude du Quaternaire, Paris: p. 15-34. (in French) (Cronostratigraphy of the Lower and Middle Paleolithic in Renania)

Bringmans, P. 2007, First evidence of Neanderthal presence in Northwest Europe during the Late Saalian "Zeifen Interstadial" (MIS 6.01) found at the VLL and VLB Sites at Veldwezelt-Hezerwater, Belgium. PalArch's Journal of Archaeology of Northwest Europe, 1(1): 1-15.

Bringsmans, P., Vermeersch, P.M., Gullentops, F., Meijs, E.P.M., Groenendijk, A.J., de Warrimont, J.-P., \& Cordy, J.-M. 2004, Human presence and lithic variability at the 
Middle Palaeolithic Valley settlements at Veldwezelt-Hezerwater (Limburg, Belgium). In: Colloquium "Neanderthals in Europe" (Demarsin, B., Ed.), Université de Liège, Liège: p. 89-100.

Caramia, F., \& Gambassini, P. 2006, Il Musteriano evoluto del Riparo del Poggio (strati 9 e 10) a Marina di Camerota - Salerno. Rassegna di Archeologia Preistorica e Protostorica, 22(A): 67-95. (in Italian) (The evoluted Mousterian of Riparo del Poggio (layers 9 and 10) at Marina di Camerota - Salerno)

Carmignani, L. 2010, L'industria litica del livello FIIIe di Grotta del Cavallo (Nardò, Lecce). Messa in evidenza di una produzione lamino - lamellare in un contesto del Musteriano finale. Origini: Preistoria e Protostoria delle Civiltà Antiche, 32 (Nuova Serie 4): 7-26. (in Italian) (The lithic industries of the FIIIe level at Grotta del Cavallo (Nardò - Lecce) Study of a blade and bladelets producution in the final Mousterian)

Carmignani, L., \& Romagnoli, F., (in press), Grotta Bernardini (scavi E. Borzatti von Lowenstern): Revisione delle industrie litiche e loro inquadramento nel contesto musteriano salentino. In: Studi di Preistoria e Protostoria Italiana. "Atti della XLVII Riunione Scientifica Preistoria e Protostoria Della Puglia, 9-13 October 2012». (in Italian) (Grotta Bernardini (research E. Borzatti von Lowenstern): Revision of the lithic industries in the Salento Mousterian context)

Cattani, L., \& Renault-Miskovsky, J. 1989, La réponse des végétations aux variations climatiques quaternaires autour des sites archéologiques du sud de la France et du nord de l'Italie. Il Quaternario, 2(2): 147-170. (in French) (The flora during tyhe climathic change across the study of some archeological sites in Southern France and northern Italy)

Cauche, D. 2007, Les cultures moustériennes en Ligurie italienne: Analyse du matériel lithique de trois sites en grotte. L'Anthropologie, 111: 254-289. (in French) (The Mousterian cultures in the italian Ligury: Analysis of the lithic material of three cave sites) doi:10.1016/j.anthro.2007.05.002

Cauche, D., \& Lebègue, F. 2008, Technologie et typologie des industries moustériennes des grottes de Grimaldi dans le contexte des cultures du Paléolithique moyen de l'Europe méditerranéenne. Archive de l'Insitute de Paleontologiel Humaine, 39: 95-100. (in French) (Technology and typology of the Mousterian industries of the Grimaldi's Caves during the Middle Paleolithic cultures in the mediterranean Europe)

Chabai, V.P., \& Sitlivyj, V. 1994, The blade component in the Middle Palaeolithic of Ukraine: Origin and evolution. In: Les industries laminaires au Paléolithique moyen, (Révillion S., \& Tuffreau, A., Eds.), Dossier de Documentation archéologique Vol. 18, Centre National de la Recherche Scientifique Éditions, Paris: p. 161-177.

Chabai, V.P., Marks, A.E. \& Monigal, K. 2004, Crimea in the context of the Eastern European Middle Paleolithic and Early Upper Paleolithic. In: The Middle Paleolithic and Early Upper Paleolithic of Eastern Crimea, Vol. 3 (Chabai V.P. Monigal, K \& Marks, A.E., Eds.), Études et Recherches Archéologiques de l'Université de Liège Vol. 104, University of Liege Press, Liège: p. 419-460.

Cliquet, D. 1992, Le gisement paléolithique moyen de Saint-Germain-des-Vaux/Port-Racine (Manche) dans son cadre régional: Essai palethnographique. $\mathrm{PhD}$ Thesis, University of Paris 1, Paris, 648 p. (in French) (The Middle Paleolithic site of Saint-Germain-desVaux/Port-Racine (English Channel) in its regional context: A paleoethnographic test) 
Conard, N.J. 1990, Laminar lithic assemblages from the last interglacial complex in Northwestern Europe. Journal of Anthropological Research, 46: 243-262. doi:10.1086/jar.46.3.3630426

Conard, N.J., \& Adler, D.S. 1997, Lithic Reduction and Hominid Behavior in the Middle Palaeolithic of the Rhineland. Journal of Anthropological Research, 53(2): 147-175. doi:10.1086/jar.53.2.3631275

Cook, J. 1986, A blade industry from Stoneham's Pit, Crayford (Kent). In: The Palaeolithic of Britain and its Nearest Neighbours: Recent Trends (Collcutt, S.N., Ed.), Department of Prehistory \& Archaeology, University of Sheffield, Sheffield: p. 16-19.

Dauvois, M. 1976, Précis de dessin dynamique et structural des industries lithiques préhistoriques. Périgeux, Fanlac, 262 p. (in French) (Structural and dynamic lithic prehistoric drawing)

Delagnes, A. 1993, Un mode de production inédit au Paléolithique moyen dans l'industrie du niveau 6e du Pucheuil (Seine-Maritime). Paléo, 5: 111-120. (in French) (An inusual type of production in the Middle Paleolithic found in the level 6e of Pucheuil (SeineMaritime)) doi:10.3406/pal.1993.1106

Delagnes, A., \& Ropars, A. 1996, Paléolithique moyen en pays de Caux (Haute-Normandie). Le Pucheuil, Etoutteville: deux gisements de plein air en milieu loessique Vol. 56. Éditions de la Maison des Sciences de l'Homme, Paris, 243 p. (in French) (The Middle Paleolithic in the Caux countries, (High-Normandy). The Pucheuil and Etouteville sites: two open air deposits in a loessic environment)

Depaepe, P., Antoine, P., Guerlin, O., \& Swinnen, C. 1999, Le gisement paléolithique moyen de Blangy-Tronville (Somme). Revue Archéologique de Picardie, 3(1): 3-21. (in French) (The Middle Paleolithic site of Blangy-tronville, (Somme))

Dini, M., Mezzasalma, S., \& Tozzi, C. 2007, Il Paleolitico medio di Grotta La Fabbrica (Parco dell'Uccellina - Grosseto). In: Atti del Museo di Storia Naturale della Maremma, Supplemento al n. 22 (Cavanna, C. Ed), Società Naturalistica Speleologica Maremmana, Grosseto: p. 31-52. (in Italian) (The Middle Paleolithic of Grotta la Fabbrica. (Natural park of Uccelina - Grosseto))

Dini, M., \& Koehler, H. 2009, The contribution of new methodological approaches to explaining the Final Middle Paleolithic of the Apuane Alps (Tuscany, Italy). Human Evolution, 24(1): 13-25.

Faivre, J.P. 2012, A material anecdote but technical reality. Bladelet and small blade production during the recent Middle Paleolithic Combe-Grenal rock shelter. Lithic Technology, 37(1): 5-24. doi:10.1179/lit.2012.37.1.5

Fontana, F., Peretto, C., \& Nenzioni, G. 2009, First recognition of predetermined core reduction sequences in the Southern Po Plain area before MIS 8 at the site of Cave dall'Olio (Bologna, Italy): an "ancient series" revisited. Human Evolution, 24(1): 43-56.

Fontana, F., Moncel, M.-H., Nenzioni, G., Onorevoli, G., Peretto, C., \& Combier, J. 2013, Widespread diffusion of technical innovations around 300,000 years ago in Europe as a reflection of anthropological and social transformations? New comparative data from the western Mediterranean sites of Orgnac (France) and Cave dall'Olio (Italy). Journal of Anthropological Archaeology, 32(4): 478-498. doi:10.1016/j.jaa.2013.08.003

Forestier, H. 1993, Le Clactonien: Mise en application d'une nouvelle méthode de débitage s'inscrivant dans la variabilité des systèmes de production lithique du Paléolithique 
ancien. Paléo, 5: 53-82. (in French) (The Clactonian: The use of a new flaking strategy inside the flaking systems variability of the ancient Paleolithic) doi:10.3406/pal.1993.1104

Gambassini, P. 1997, Il Paleolitico di Castelcivita: Culture e ambiente. Materiae Vol. 5. Electa Napoli, Napoli, 159 p. (in Italian) (The Paleolithic of Castelicivita: Culture and enviromment)

Gouédo, J.-M. 1994, Remontage d'un nucleus à lames du gisement micoquien de Vinneuf (Yonne). In: Les Industries laminaires au Paléolithique moyen (Tuffreau, A., \& Revillon, S., Eds.), Dossier de Documentation Archéologique Vol. 18, Centre National de la Recherche Scientifique Éditions, Paris: p. 77-102. (in French) (The reffitting of a blade core from the micoquian site of Vinneuf (Yonne))

Gouédo, J.M., Bats, J.C., Krier, V. Pernot, P., \& Ricard, J.L. 2004, Le gisement moustérien de la "Butte d'Arvigny", commune de Moissy-Cramayel (Seine-et-Marne). Premiers résultats. Bulletin de la Société Préhistorique Française, 91(6): 369-377. (in French) (Le site of Butte d'Arvigny, municipality of Moissy-Cramayel, (Seine-et-Marne). First results.))

Goval, E., \& Hérisson, D. 2006, Coexistence des chaînes opératoires Levallois et laminaires au sein des assemblages $\mathrm{C} 12$ et $\mathrm{C}$ de Riencourt-lès-Bapaume (Pas-de-Calais, France). Notae Prehistoricae, 26: 25-39. (in French) (Coexistence of Levallois and laminar flaking strategies in the $\mathrm{C} 12$ and C levels of Riencourt-lès-Bapaume (Pas-de-Calais, France))

Grimaldi, S. 1996, Mousterian reduction sequences in central Italy. Quaternaria Nova, (Nuova Serie), 6: 279-310.

Grimaldi, S., \& Santaniello, F. 2014, New insights into Final Mousterian lithic production in western Italy. Quaternary International, 350: 116-129. doi:10.1016/j.quaint.2014.03.057

Guilbaud, M., \& Carpentier, G. 1995, Un remontage exceptionnel à Tourville-la-Rivière (Seine- Maritime). Bulletin de la Société Préhistorique Française, 92: 289-295. (in French) (An exceptional refitting at Tourville-la-Rivière, Seine- Maritime)

de Heinzelin, J., \& Haesaerts, P. 1983, Un cas de débitage laminaire au Paléolithique ancien: Croix-1'Abbé à Saint-Valery-sur-Somme. Gallia Préhistoire, 26(1): 189-201. (in French) (A case of a blade production in the Ancient Paleolithic: Croix-l'Abbé à SaintValery-sur-Somme) doi:10.3406/galip.1983.1716

Inizan, M.L., Reduron, M., Roche, H., \& Tixier, J. 1995, Technologie de la pierre taillée. Préhistoire de la pierre taillée, Vol. 4, Edition du Cercle de Recherche et d'Etude Prehistorique, Meudon, 199 p. (in French) (Technology of the lithic strategy. Preistory of the lithic strategy)

Johnson, C.R., \& McBrearty, S. 2010, 500,000 year old blades from the Kapthurin Formation, Kenya. Journal of Human Evolution, 58(2): 193-200. doi:10.1016/j.jhevol.2009.10.001

Koehler, H. 2008, L'apport du gisement des Osiers à Bapaume (Pas-de-Calais) au débat sur l'émergence du Paléolithique moyen dans le Nord de la France. Bulletin de la Société préhistorique française, 105(4): 709-735. (in French) (The contribution of the site of Osiers à Bapaume to the debates concerning the begining of the Middle Paleolithic in northern France) doi:10.3406/bspf.2008.13781 
Le Tensorer, J.M. 2005, Le Yabroudien et la transition du Paléolithique ancien au Paléolithique moyen en Syrie: l'Exemple d'El Kowm. Munibe, AnthropologiaArkeologia, 57(2): 71-82. (in French) (The Yabrudian and the transition from the Lower Paleolithic to the Middle Paleolithic in Syria: The exemple of El Kowm) URL: http://www.aranzadi.eus/fileadmin/docs/Munibe/200502071082AA.pdf

Lemorini, C. 2000, Reconnaître des tactiques d'exploitation du milieu au Paléolithique moyen. La contribution de l'analyse fonctionnelle; étude fonctionnelle des industries lithiques de la Grotta Breuil (Latium, Italie) et de la Combette (Bonnieux, Vaucluse, France). British Archeological Report International Series Vol. 858, Archaeopress, Oxford, 142 p. (in French) (Recognition of the exploitation strategies of a Middle Paleolithic enviroment. The contribution of the functional analysis; functional study of the lithic industries of Grotta Breuil (Latium, Italy) and la Combette (Bonnieux, Vaucluse, France))

Li, Y.H., \& Bodin, É. 2013, Variabilité et homogénéité des modes de débitage en Chine entre 300.000 et 50.000 ans. L'Anthropologie, 117(5): 459-493. (in French) (Variability and homogeneity of the reduction strategy in China between 300.000 and 50.000 years) doi:10.1016/j.anthro.2013.10.001

Loch, J.-L. 2002, Bettencourt-Saint-Ouen (Somme): Cinq occupations paléolithiques au début de la dernière glaciation. Documents d'archéologie Française no. 90. Maison des Sciences de l'Homme, Paris: p. 5-169. (in French) (Five Paleolithic settlements at the beginning of the last glaciation)

Locht, J.-L. \& Depaepe P. 1994, Exemples de débitage laminaire dans cinq sites de la vallée de la Vanne (Yonne): In: Les industries laminaires au Paléolithique moyen (Tuffreau, A., \& Revillon, S., Eds.). Dossier de Documentation Archéologique Vol. 18, Centre National de la Recherche Scientifique Éditions, Paris: p. 103-116. (in French) (Exemples of blade reduction systems in five sites of the Vanne valley (Yonne))

Locht, J.-L., \& Ferdouel, F. 1994, Lailly / Le Domaine de Beauregard (vallée de la Vanne). In: Le Paléolithique moyen dans le nord du Sénonais (Yonne) (Deloze, V., Depaepe, P., Gouédo, J.-M., Krier, V., \&, Locht, J.-L., Eds.), Maison des Sciences de l'Homme, Paris: p. 139-162. (in French) (Lailly / Le Domaine de Beauregard (Vanne valley))

Locht, J.-L., Antoine, P., Hérisson, D., Gadebois, G., \& Debenham, N. 2010, Une occupation de la phase ancienne du Paléolithique moyen à Therdonne (Oise). Chronostratigraphie, production de pointes Levallois et réduction des nucleus. Gallia Préhistoire, 52: 1-32. (in French) (A settlement during the ancient phase of the Middle Paleolithic at Therdonne (Oise)) doi:10.3406/galip.2010.2469

Maíllo Fernández, J. M. 2001, Aproximación al fenómeno laminar en el Paleolítico medio: El ejemplo de la Cueva Morín (Villanueva de Villaescusa, Cantabria). Espacio Tiempo $Y$ Forma. Serie I, Prehistoria Y Arqueología, 14: 79-105. (in Spanish) (Estimating the blade phenomenon in the Middle Paleolithic: The case of Cueva Morin, Morín (Villanueva de Villaescusa, Cantabria))

Maíllo-Fernández, J.M., Cabrera-Valdès, V., \& Bernaldo de Quirós, F. 2004, Le débitage lamellaire dans le Moustérien final de Cantabrie (Espagne): Le cas de El Castillo et Cueva Morin. L'Anthropologie, 108(3-4), 367-393. (in French) (The bladelets reduction systems in the final Mousterian of Cantabria region (Spain): The case of El Castillo and Cueva Morin) doi:10.1016/j.anthro.2004.10.009 
Meignen, L. 1994, Paléolithique moyen au Proche-Orient: Le phénomène laminaire. In: Les industries laminaires au Paléolithique Moyen (Tuffreau, A., \& Revillon, S., Eds.), Dossier de Documentation Archéologique, 18, Centre National de la Recherche Scientifique Éditions, Paris: p. 125-159. (in French) (The Middle Paleolithic in the Middle-East: The blade phenomenon.)

Meignen, L. 2007, Le phénomène laminaire au Proche-Orient, du Paléolithique inférieur aux débuts du Paléolithique supérieur. In: Un Siècle de Construction Du Discours Scientifique En Préhistoire, XXVI ${ }^{\circ}$ Congrès de La Société Préhistorique Française, Avignon 2004, (Evin, J., Ed.), Société Préistorique Francaise, Avignon: p. 79-94. (in French) (The blade phenomenon in the Middle-East, from the Lower Paleolithic to the Upper Paleolithic)

Meignen, L. 2011, Contribution of Hayonim cave assemblages to the understanding of the socalled Early levantine Mousterian. In: The lower and middle palaeolithic in the middle east and neighbouring regions (Le Tensorer, J.-M., Jagher, R., \& Otte, M., Eds.), Études et Recherches Archéologiques de l'Université de Liège Vol. 126, University of Liege Press, Liège: p. 85-100.

Meignen, L., \& Tushabramishvili, N. 2006, Paléolithique moyen Laminaire sur les flancs sud du Caucase: Productions lithiques et fonctionnement du site de Djruchula (Géorgie). Paléorient, 32(2): 81-104. (in French) (Blade Middle Paleolithic on the southern Caucasus: Lithic production and function of the Djruchula site(George)) doi:10.3406/paleo.2006.5191

Meignen, L., \& Tushabramishvili, N. 2010, Djruchula Cave, on the Southern Slopes of the Great Caucasus: An Extension of the Near Eastern Middle Paleolithic Blady Phenomenon to the North. Journal of the Israel Prehistoric Society, 40: 35-61.

Mercier, N., \& Valladas, H. 2003, Reassessment of TL age-estimates of burnt flints from the Paleolithic site of Tabun Cave, Israel. Journal of Human Evolution, 45: 401-409. doi:10.1016/j.jhevol.2003.09.004

Moncel, M.-H. 1996, L'industrie lithique du Paléolithique moyen de l'abri du Maras (Ardèche). Gallia Préhistoire, 38(1): 1-41. (in French) (The Middle Paleolithic lithic industries of the Abris du Maras (Ardéche)) doi:10.3406/galip.1996.2143

Moncel, M.-H. 2005, Baume Flandin et Abri du Maras: Deux exemples de débitage laminaire du début du Pléistocène supérieur dans la Vallée du Rhône (sud-est, France). L'Anthropologie, 109(3): 451-480. (in French) (Baume Flandin and Abri du Maras: Two exemples of blade production at the beginning of the Upper Pleistocene in the Rhone valley (South-East France)) doi:10.1016/j.anthro.2005.06.002

Moncel, M.-H., Crégut-Bonnoure, É., Daujeard, C., Lartigot, A.S., Lebon, M., Puaud, S., \& Croizet, S. 2008, Le site de la Baume Flandin (commune d'Orgnac-l'Aven): Nouvelles données sur ce gisement du Paléolithique moyen. Comptes Rendus Palevol, 7(5): 315325. (in French) (The Baume Flandin site (municipality of Orgnac-l'Aven): New data of this middle Paleolithic site.)) doi:10.1016/j.crpv.2008.03.005

Otte, M. 1994a, Rocourt (Liège, Belgique): Industrie laminaire ancienne. In. Les industries laminaires au Paléolithique moyen (Tuffreau, A., \& Revillon, S., Eds.), Dossier de Documentation Archéologique Vol.18, Centre National de la Recherche Scientifique Éditions, Paris: p. 180-186. (in French) (Rocourt (Liege, Belge): Ancient blade assemblages.)) 
Otte, M. 1994b, Origine de l'homme moderne: Approche comportementale. Comptes Rendus de l'Académie des Sciences de Paris, 318(2), 267-273. (in French) (The modern human origin: Behavioural approach)

Pasa, A., \& Mezzena F. 1964. Riparo Tagliente (Grezzana, Verona). Rivista di Scienze Preistoriche, 19: 295-296. (in Italian) (Riparo Tagliente (Grezzana, Verona)

Pastoors, A., \& Tafelmaier, Y. 2010, Bladelet production, core reduction strategies, and efficiency of core configuration at the Middle Palaeolithic site Balver Höhle (North Rhine Westphalia, Germany). Quartär, 57: 25-41. doi:10.7485/QU57_02

Pelegrin, J. 1991, Sur une recherche technique expérimentale des techniques de débitage laminaire. In: Archéologie expérimentale. Tome 2: La Terre: l'Os et la pierre, la maison et les champs, Archéologie aujourd'hui, editions Errance, Paris: p. 118-128. (in French) (On the experimental research of the blade reduction systems technique)

Pelegrin, J. 1995, Technologie lithique: Le Châtelperronien de Roc-de-Combe (Lot) et de la Côte (Dordogne). Cahiers du Quaternaire Vol. 20, Centre National de la Recherche Scientifique Éditions, Paris, 297 p. (in French) (Lithic technology: The Chatelperronian of Roc-de-Combe (Lot) and Côte (Dordogne))

Pelegrin, J. 2000, Les techniques de débitage laminaire au Tardiglaciaire: Critères de diagnose et quelques réflexions. In: L'Europe centrale et septentrionale au Tardiglaciaire (Valentin, B., Bodu, P., \& Christensen, M., Eds.), Mémoires du Musée de Préhistoire d'Île-de-France Vol. 7, Association Pour la Promotion de la Recherche Archéologique en Ile-de-France, Nemours: p. 73-86. (in French) (Blade technology during the late glacial: Screening criteria and some theorethical consideration)

Peng, F., Wang, H., \& Gao, X. 2014, Blade production of Shuidonggou Locality 1 (Northwest China): A technological perspective. Quaternary International, 347: 12-20. doi:10.1016/j.quaint.2014.04.041

Peresani M. 1995, Sistemi tecnici di produzione litica nel Musteriano d'Italia. Studio tecnologico degli insiemi litici delle unità VI e II della Grotta di San Bernardino (Colli Berici, Veneto). Rivista di Scienze Preistoriche, 47: 79-167. (in Italian) (The lithic production systems in the Italian Mousterian. Technological studies of the Grotta di San Bernardino lithic collection, units 6 and 2 (Berici Mountains, Veneto))

Peresani, M. 1996, The Levallois reduction strategy at the Cave of San Bernardino (Northern Italy). In: Reduction Processes (chaînes opératoires) in the European Mousterian. Proceedings International Round Table (Bietti A., \& Grimaldi S., Eds.), Quaternaria Nova, 6: 205-236.

Peresani M. 1998, La variabilité du débitage discoïde dans la grotte de Fumane (Italie du Nord), Paléo, 10: 123-146. (in French) (The Discoid varibility at the Fumane Cave (Northern Italy)) doi:10.3406/pal.1998.1133

Peresani, M. 2012, Fifty thousand years of flint knapping and tool shaping across the Mousterian and Uluzzian sequence of Fumane cave. Quaternary International, 247 : 125-150. doi:10.1016/j.quaint.2011.02.006

Peresani, M., \& Porraz, G. 2004, Ré-interprétation et mise en valeur des niveaux moustériens de la Grotte du Broion (Monti Berici, Vénétie). Etude techno économique des industries lithiques. Rivista di Scienze Preistoriche, 54: 181-248. (in French) (Revisioning and development of the Grotte du Broin Mousterian levels (Berici mountains, Veneto region)) 
Peresani, M., \& Centi Di Taranto, L.E. 2013, Blades, bladelets and flakes: A case of variability in tool design at the dawn of the Middle-Upper Palaeolithic transition in Italy. Comptes Rendus Palevol, 12(4): 211-221. doi:10.1016/j.crpv.2013.02.005

Peretto, C. (Ed.) 2012, L 'insediamento musteriano di Grotta Reali, Rocchetta a Volturno, Molise, Italia. Annali dell'Università degli Studi di Ferrara, Sezione Museologia Scientifica e Naturalistica, Vol. 8/2, Università degli studi di Ferrara, Ferrara, 172 p. (in Italian) (The Mousterian site of Grotta Reali, Rocchetta la Volurno, Molise, Italy)

Révillion, S. 1995, Technologie du débitage laminaire au Paléolithique moyen en Europe septentrionale: État de la question. Bulletin de la Société Préhistorique Française, 92(4): 425-442. (in French) (Middle Paleolithic blade technology in northern Europe: State of the knowledge.) doi:10.3406/bspf.1995.10058

Révillion, S., \& Cliquet, D. 1994, Technologie du débitage laminaire du gisement paléolithique moyen de Saint-Germain-des-Vaux / Port Racine (secteur I) dans le contexte des industries du Paléolithique moyen du Massif Armoricain. In: Les industries laminaires au Paléolithique moyen (Tuffreau, A., \& Revillon, S., Eds.), Dossier de Documentation Archéologique, Vol. 18, Centre National de la Recherche Scientifique Éditions, Paris: p. 45-62. (in French) (Blade technology of the middle palolithic sites of Saint-Germain-des-Vaux / Port Racine (sector I) in the context of the middle Paleolithic assemblages of the Armoricain plateau.)

Révillion, S., \& Tuffreau, A. 1994, Valeur et signification du débitage laminaire du gisement paléolithique moyen de Seclin Nord. In: Les industries laminaires au Paléolithique moyen (Tuffreau, A., \& Revillon, S., Eds.), Dossier de Documentation Archéologique, 18, Centre National de la Recherche Scientifique Éditions, Paris: p. 19-43. (in French) (Value and meaning of the blade reduction systems in the middle Paleolithic site of Seclin North.)

Richter, D., Hauck, T., Wojtzack, D., Le Tensorer, J.-M., \& Muhesen, S. 2011, Chronometric age estimates for the site of Hummal (El Kowm, Syria). In: The lower and middle palaeolithic in the middle east and neighbouring regions (Le Tensorer, J.-M., Jagher, R. \& Otte, M., Eds.), Études et Recherches Archéologiques de l'Université de Liège Vol. 126, University of Liege Press, Liège: p. 249-261.

Sarti, L., Carmignani, L., Romagnoli, F., Martini, F., Ghinassi, M., \& Sala, B. (in press), Grotta del Cavallo (scavi L. Sarti): Tradizione e innovazione nella sequenza musteriana sulla base dell'indicatore litico. In: Studi di Preistoria e Protostoria italiana. " Atti della XLVII Riunione Scientifica Preistoria e Protostoria Della Puglia, 9-13 October $2012 »$. (in Italian) (Cavallo cave (research L. Sarti): Tradition and innovation in the Mousterian sequences on the basis of the lithic data)

Schäfer, J., \& Ranov, V.A. 1998, Middle Paleolithic blades industries and the Upper Paleolithic of central Asia. In: Préhistoire d'Anatolie, genèse des deux mondes (Otte, M., Ed.), Études et Recherches Archéologiques de l'Université de Liège Vol. 85, University of Liege Press, Liège: p. 785-814.

Schäfer, J., Ranov, V., \& Sosin, P. 1998, The cultural evolution of man and the chronostratigraphical background of changing environments in the loess palaeosoil sequences of Obi-Mazar and Khonako (Tadjikistan). Anthropologie, 36:121-135.

Schäfer, J., Laurat, T., Ranov, V.A., \& Sosin, P.M. 2003, Das Altpalaolithikum aus dem 4. Palaobodenkomplex von Obi-Mazar (Tadschikistan). In: Erkenntnisjäger - Kultur und Umwelt des frühen Menschen - Festschrift für Dietrich Mania (Meller, H., 
Burdukiewicz, J.M., Fiedler, L. Heinrich W.-D., Justus, A., \& Brühl, E., Eds.), Veröffentlichungen des Landesamtes für Archäologische Denkmalpflege, SachsenAnhalt, Landesmuseum für Vorgeschichte, Vol. 57, Halle: p. 509-535. (in German) (The lower Palaeolithic from the $4^{\text {th }}$ Palaoboden complex of Obi-Mazar (Tajikistan))

Skrdla, P. 2003, Comparison of Boker Tachtit and Stránská skála MP/UP transitional industries. Journal of the Israel Prehistoric Society, 33: 37-73. URL: http://www.iabrno.cz/skrdla/BokerT.pdf

Slimak, L. 1999, Mise en évidence d'une composante laminaire et lamellaire dans un complexe moustérien du sud de la France, Paléo, 11: 89-109. (in French) (Recognition of a blade and bladelets production in a southern France Mousterian site) doi:10.3406/pal.1999.1172

Slimak L. 2003, Les débitages Discoïdes moustériens: Évaluation d'un concept technologique, In: Discoid lithic technology. Advances and implications (Peresani M. Ed.), British Archaeological Reports Vol. 1120, Archeopress, Oxford: p. 33-66. (in French) (The Mousterian discoid reduction system: Evaluation of a technological concept)

Slimak, L., \& Lucas, G. 2005, Le débitage lamellaire, une invention aurignacienne? In: Productions lamellaires attribuées à l'Aurignacien. Chaînes opératoires et perspectives technoculturelles (Le Brun-Ricalens, F., Ed.), Imprimerie Fr. Faber, Luxemburg: p. 75102. (in French) (Bladelets production, an Aurignacian invention?)

Soressi, M. 2002, Le Moustérien de tradition acheuléenne du sud-ouest de la France. Discussion sur la signification du faciès à partir de l'étude comparée de quatre sites: Pech-de-l'Azé I, Le Moustier, La Rochette et la Grotte XVI. Ph.D. Thesis, Université de Bordeaux I, Bordeaux: 339 p. (in French) (The Mousterian of Acheulan tradition in the south-western France. Discussion about the meaning of the faces starting from a study comparaison of four sites: Pech-de-l'Azé I, Le Moustier, La Rochette et la Grotte XVI)

Soressi, M. 2005, Late Mousterian lithic technology: Its implications for the pace of the emergence of behavioural modernity and the relationship between behavioural modernity and biological modernity. In: From Tools to Symbols (Backwell, L., \& d'Errico, F., Eds.), University of Witwatersrand Press, Johannesburg: p. 389-417. URL: http://www.eva.mpg.de/evolution/staff/soressi/pdf/Soressi2005_ToolsToSymbols.pdf

De Stefani, M., Dini, M., Klempererova, H., Peresani, M., Ranaldo, F., Ronchitelli, A., \& Ziggiotti, S. 2012, Continuity and replacement in flake production across the MiddleUpper Palaeolithic transition: A view over the Italian Peninsula. In: Flakes not Blades: The Role of Flake Production at the Onset of the Upper Palaeolithic in Europe (Pastoors, A., \& Peresani, M., Eds.), Wissenschaftliche Schriftendes Neanderthal Museums Vol. 5, Neanderthal Museum, Mettmann: p. 135-151.

Svoboda, J., \& Skrdla, P. 1995, The Bohunician Technology. In: The Definition and Interpretation of Levallois Technology (Dibble H.L., \& Bar-Yosef O., Eds.), Monographs in World Archaeology Vol. 23, Prehistory Press, Madison, Wisconsin: p. $432-438$

Tavoso, A. 1988, L'outillage du gisement de San Francesco à San Remo (Ligurie, Italie):

Nouvel examen. In: L'homme de Néanderthal, Vol. 8 (Otte, M., \& Kozlowski, J., Eds.), La Mutation, Actes du Colloque International de Liége (4-7 décembre 1986) Vol. 35, Etudes et Recherche Archéologique De l'Université de Liege, Liège: p. 193-210. (in French) (The tools of the deposit of San Francesco a San Remo (Liguria, Italy)) 
Thun-Hohenstein, U., \& Peretto, C. 2005, Faunal exploitation in the Middle Palaeolithic: Evidences from Riparo Tagliente (Verona, Italy). In: Actes du Colloque International: Données récentes sur les modalités de peuplement et sur le cadre chronostratigraphique, géologique et paléogéographique des industries du Paléolitique inferieur et moyen en Europe (Molines, N., Moncel, M.-H., \& Monnier, J.-L., Eds.), British Archeological Report International Series Vol. 1364, Archaeopress, Oxford: p. 261-267.

Villa, P., Boscato, P., Ranaldo, F., \& Ronchitelli, A. 2009, Stone tools for the hunt: points with impact scars from a Middle Paleolithic site in southern Italy. Journal of Archaeological Science, 36(3): 850-859. doi:10.1016/j.jas.2008.11.012

Wenban-Smith, F.F. 1992, Early Palaeolithic cultural facies and the Levalloisian at Baker's Hole. Papers from the Institute of Archaeology, 2: 1-10. doi:10.5334/69

Wilkins, J., \& Chazan, M. 2012, Blade production 500 thousand years ago at Kathu Pan 1, South Africa: Support for a multiple origins hypothesis for early Middle Pleistocene blade technologies. Journal of Archaeological Science, 39(6): 1883-1900. doi:10.1016/j.jas.2012.01.031

Wilson, L., \& Browne, C.L. 2014, Change in raw material selection and subsistence behaviour through time at a Middle Palaeolithic site in southern France. Journal of Human Evolution, 75: 28-39. doi:10.1016/j.jhevol.2013.12.018

Yamada, M. 1997, L’industrie lithique moustérienne de la Barma Grande aux Balzi Rossi (Ligurie, Italie). L'Anthropologie, 101(3): 512-521. (in French) (The Mousterian lithic industries of Barma Grande at Balzi Rossi (Liguria, Italy))

Yamada, M. 2004, Dernière production lithique moustérienne de l'Abri Mochi aux Balzi Rossi (Ligurie, Italie). Quaternaria nova, 7: 19-35. (in French). (The last Mousterian lithic production at Abri Mochi, Balzi Rossi (Liguria, Italy))

Zorzi, F. 1962, Provincia di Verona, Grezzana, Rivista di Scienze Preistoriche, 17: 284-285. (in Italian) (Province of Verona, Grezzana)

Zorzi, F., \& Mezzena, F. 1963, Provincia di Verona, Grezzana. Rivista di Scienze Preistoriche, 18: 307-308. (in Italian) (Province of Verona, Grezzana) 